\section{W.F. Albright Institute of \\ Archaeological Research}

P.O. Box 19096, Jerusalem 9119002, Israel.

Tel: $\quad$ (972) 26288956

Email:_albrightinstitute@aiar.org

Website: www.aiar.org/

The W.F. Albright Institute of Archaeological Research is a non-profit organization formed to engage in and facilitate research on the history and cultures of the Near East, to document and preserve evidence from the ancient world as a cultural resource, and to educate the public about the history and cultures of the region.

\section{Sean W. Dever Memorial Prize}

Purpose: The W.F. Albright Institute of Archaeological Research in Jerusalem announces the Sean W. Dever Memorial Prize call for papers.

Eligibility: Authors must be Ph.D. candidates in the semester in which the winner is announced (Spring).

Level of Study: Doctorate, Postdoctorate

Type: Prize

Value: US\$750

Frequency: Annual

Country of Study: Israel

Closing Date: 15 January

Funding: Private

Additional Information: All submissions must be in PDF format only. Conference papers must include images (if used in the presentation) in PDF format (either as a separate document or embedded within the text of the paper), and full citations and bibliographic references.

\section{Wageningen University}

Droevendaalsesteeg 4, NL-6708 PB Wageningen, Netherlands.

Tel:

$$
\text { (31) } 317480100
$$

Website: www.wur.nl/en/wageningen-university.htm

Contact: Wageningen University and Research

Wageningen University and Research is a collaboration between Wageningen University and the Wageningen Research foundation. The strength of Wageningen University and Research lies in its ability to join the forces of specialised research institutes and the university. It also lies in the combined efforts of the various fields of natural and social sciences. This union of expertise leads to scientific breakthroughs that can quickly be put into practice and be incorporated into education.

\section{Wageningen University \& Research Africa Scholarship Program}

Purpose: Applications are open for the Wageningen University and Research Africa Scholarship Program. The Africa Scholarship Program (ASP) has been initiated by Wageningen University and Research to give talented and motivated students from Africa the opportunity to study at the university in Wageningen.

Eligibility: 1. You are a citizen of an African country. 2. You are an excellent student with a First class honours degree or a GPA of $80 \%$ or higher in a Bachelor degree. 3. You have applied for one the master's programmes of Wageningen University and Research.

Level of Study: MBA, Masters Degree, Postgraduate, Postgraduate (MSc)

Type: Scholarship 
Length of Study: 2 years

Frequency: Annual

Country of Study: Any country

No. of awards offered: 10

Closing Date: 15 January

Funding: Foundation

Additional Information: Only candidates who have been invited for the ASP selection have received an e-mail. If you have not received an invitation to apply for this scholarship, you have not been selected to participate.

\section{Wal-Mart Foundation}

702 S.W. 8th Street, Bentonville, AR 72716, United States of America.

Tel: (1) 8005309925

Website: www.fconline.foundationcenter.org/fdograntmaker-profile?key=WALM001

The Walmart Foundation was created to help support the communities Walmart serves. We focus on areas where we can do the most good - combining the unique strengths of the business alongside our philanthropy. Our ability to draw on Walmart business strengths, providing more than just funding, enables our philanthropy to deliver greater societal impact.

\section{Walmart Dependent Scholarship}

Purpose: This award is for graduating high school seniors who are dependents of actively employed Walmart associates within any division of Walmart for at least six consecutive months as of the application deadline. Students must have a grade point average of 2.0 or higher and must demonstrate financial need. Eligibility: 1. Must be an undergraduate student. 2. Must attend a university, two-year college or a vocational-tech school. 3. Citizenship requirements: US. 4. Must currently be a high school student. 5. Must study full-time. 6. Requires corporate affiliation of Wal-Mart Foundation.

Level of Study: Graduate

Type: Scholarship

Value: US $\$ 13,000$

Frequency: Annual

Country of Study: United States of America

Application Procedure: 1. Application Form. 2. Financial Need Analysis. 3. Contact - walmartdependent@applyISTS.com

No. of awards offered: Varies

Closing Date: 2 April

Funding: Foundation

\section{Warsaw Agricultural University The International Institute of Management and Marketing in Agri-Business (IZMA)}

Nowoursynowska 166, PL-02 787 Warsaw, Poland.

Tel:

(48) 225931000

Email: izma@sggw.waw.pl

Website: www.sggw.pl/en/

Contact: MBA Admissions Officer

The Warsaw University of Life Sciences is the largest agricultural university in Poland, established in 1816 in Warsaw. It employs over 2,600 staff including over 1,200 academic educators. The University is since 2005 a member of the Euroleague for Life Sciences which was established in 2001.

\section{Warsaw Agricultural University MBA in Agribusiness Management}

\section{Length of Study: $2-5$ years}

Application Procedure: Applicants must supply an application form together with the following: transcripts from previous institutions, a leaving school certificate, three passport photos, a certificate of physical fitness, relevant identification documents. All documents must be translated into Polish by an official translator.

For further information contact:

Tel: $\quad$ (48) 228439751

Fax: (48) 228431877

Email: majewski@alpha.sggw.waw.pl

\section{Washington Conservation Guild}

P.O. Box 553, Kensington, MD 20895, United States of America.

Email: wcg@washingtonconservationguild.org

Website: www.washingtonconservationguild.org/

The Washington Conservation Guild (WCG) is a 501(c) (3) nonprofit organization of conservation professionals dedicated to preserving art and historic materials. Founded in 1967, WCG serves as a regional forum for its members and as a resource to the public for learning about the care of personal collections. 


\section{National Air and Space Museum - Engen Conservation Fellowship}

Purpose: Fellows will be encouraged to develop a research project while at NASM. The independent research will be derived from the diverse collection of materials and may be related to evaluations of treatment procedures, ethical considerations, or technical studies.

Eligibility: 1. The ideal candidate will have a Master's degree in conservation from a recognized program and be able to conduct research independently. The candidate should have knowledge of ethical and professional principles and concepts related to the preservation of objects in a wide variety of media. 2 . They should also understand the theories, principles, techniques, practices, and methodologies used to examine, study, treat, analyze and preserve historic objects. 3. Applicants should have a proven record of research, writing ability, and verbal communication skills.

Level of Study: Graduate, Postgraduate

Type: Fellowship

Frequency: Annual

Country of Study: Any country

Closing Date: 15 January

Funding: Private

Additional Information: www.washingtonconservationguild. org/2017/11/05/nasm-engen-conservation-fellowship/

\section{For further information contact:}

Washington Conservation Guild, P.O. Box 553, Kensington, MD 20895, United States of America.

Email:Horelick1@si.edu

\section{Smithsonian Post-Graduate Paintings Conservation Fellowship with NMAAHC and $\mathrm{MCl}$}

Purpose: The fellow will be invited to participate in the survey, treatment, and exhibition of paintings and will be invited to participate in the preventive care in painting storage at NMAAHC's Visual Art Collection and conduct technical.

Level of Study: Postgraduate

Type: Fellowship

Value: US $\$ 40,000$

Length of Study: 1 year

Frequency: Annual

Application Procedure: Applications for this opportunity are being accepted through the www.solaa.si.edu/solaa/ SOLAAHome.html

Closing Date: 31 May
Additional Information: www.washingtonconservationguild. org/2020/02/06/2020-smithsonian-post-graduate-paintingsconservation-fellowship-nmaahc-mci/

\section{For further information contact:}

Fax: (1) 3012381231

Email: andersonrs@si.edu, tsangj@si.edu

\section{Washington University}

Graduate School of Arts and Sciences, Box 1186, 1 Brookings Drive, St. Louis, MO 63130-4899, United States of America.

Tel: (1) 3149355000

Email: graduateartsci@wustl.edu

Website: www.wustl.edu/

Contact: Dr Nancy P. Pope, Associate Dean

Washington University has a diverse offering of events, disciplines, people, and resources that create unlimited possibilities for discovery and growth. The Graduate School of Arts and Sciences signals a curriculum and place, a core of teaching, learning, and discovery at Washington University.

\section{Olin School of Business Washington University MBA Programme}

Purpose: Our Program Focuses on Practicing and Mastering Management Concepts.

Eligibility: 1. Admission to the Olin MBA Program is competitive. 2. Each applicant is carefully considered by the Olin Admissions Committee-using both objective and subjective criteria-and there is no formula used to arrive at a decision. 3. Rather, the Admissions Committee takes a holistic approach to candidate evaluation with specific interest in your academic ability, professional potential, leadership qualities, communication and interpersonal skills, demonstrated achievements, motivation, and diversity.

Level of Study: MBA, Masters Degree

Type: Programme

Length of Study: 2 years

Frequency: Annual

Country of Study: Any country

Application Procedure: 1. Resume. 2. Three required essays. 3. Standardized test scores. 4. Academic transcripts and One professional recommendation.

Closing Date: 24 March 
Additional Information: There is no application fee for the Full-time MBA Program.

\section{Washington American Indian Endowed Scholarship}

Purpose: The award is based on the financial need of the student. Recipients are selected on the basis of academic merit and a commitment to serve the American Indian community in Washington.

Eligibility: Applicants must meet the following criteria: 1. Demonstrate financial need based on a completed FAFSA (Free Application for Federal Student Aid). 2. Meet Washington State residency requirements for financial aid. 3. Intend to enroll full-time as an undergraduate or graduate student at a participating public or private college or university in Washington State by fall term of the application year. 4. Intend to use your education to benefit Washington's American Indian community. 5. Not pursue a degree in theology. 6. Not yet have received a total of five years of this scholarship.

Level of Study: Graduate

Type: Scholarship

Value: US\$500 to US $\$ 2,000$

Length of Study: Up to 5 years

Frequency: Annual

Country of Study: United States of America

Application Procedure: Recipients must submit a renewal application each year for award consideration. Renewals are for one academic year, decided on a competitive basis, and at the discretion of the committee after a thorough review of the applicant's renewal application, letters of recommendation, academic merit, and continued commitment to return service to the American Indian community inWashington.

No. of awards offered: Varies

Closing Date: 1 March

Funding: Private

\section{Wellcome Trust}

Gibbs Building, 215 Euston Road, London NW1 2BE, United Kingdom.

Tel: (44) 2076118888

Email: grantenquiries@wellcome.ac.uk

Website: www.wellcome.ac.uk

The Wellcome Trust's mission is to foster and promote research with the aim of improving human and animal health.
The Trust funds most areas of biomedical research and funds research in the history of medicine, biomedical ethics, public engagement of science.

\section{Arts Awards}

Purpose: Arts Awards support imaginative and experimental arts projects that investigate biomedical science.

Eligibility: The scheme is open to a wide range of people including, among others, artists, scientists, curators, filmmakers, writers, producers, directors, academics, science communicators, teachers, arts workers and education officers. Applicants are usually affiliated to organizations, but can apply as individuals. Organizations might include: museums and other cultural attractions; arts agencies; production companies; arts venues; broadcast media; schools; local education authorities; universities and colleges; youth clubs; community groups; research institutes; the NHS; and science centres. Partnership projects (between different people and organizations, e.g. scientists and ethicists, educators and artists) are welcomed. If this is the first time an organization is applying to the Wellcome Trust an eligibility assessment will be carried out. For this assessment, the following documentation from the applying organization should be submitted: articles of association; audited accounts from the previous 2 years; details of similar projects/grant funding received; confirmation that no funding has been received or is scheduled to be received from any tobacco company.

\section{Level of Study: Research}

Type: Award

Value: Funding can be applied for at two levels: (1) Small to medium-sized projects (up to and including $£ 40,000$ ). This funding can either be used to support the development of new project ideas, deliver small-scale productions or workshops, investigate and experiment with new methods of engagement through the arts, or develop new collaborative relationships between artists and scientists and (2) Large projects (above $£ 40,000$ ). This funding can be used to fund full or part production costs for large-scale arts projects that aim to have significant impact on the public's engagement with biomedical science. We are also interested in supporting high-quality, multi-audience, multi-outcome projects. Applicants can apply for any amount within the above boundaries, for projects lasting a maximum of 3 years.

Frequency: Annual

Application Procedure: Application form for awards up to and including $£ 40,000$, preliminary application form for awards over $£ 40,000$.

\section{Funding: Trusts}

Additional Information: Applicants must be based in the United Kingdom or the Republic of Ireland and the activity must take place in the United Kingdom or the Republic 
of Ireland www.unigo.com/scholarships/by-major/dancescholarships/washington-american-indian-endowed-scholar ship/1905

\section{For further information contact:}

Tel: (44) 2076115757

Email: PEgrants@wellcome.ac.uk

\section{Broadcast Development Awards}

Purpose: To support the development of broadcast proposals in any genre that engages the audience with issues around biomedical science in an innovative, entertaining and accessible way.

Eligibility: The proposal must primarily be aimed at a mainstream United Kingdom and/or Republic of Ireland audience in the first instance but the subject matter can be international. Applicants are usually affiliated to organizations, but can apply as individuals. The scheme is open to broadcast professionals and other organizations or individuals working on broadcast projects. Partnership between broadcasters and other professionals such as scientists, ethicists, educators etc. are especially welcomed.

Level of Study: Research

Type: Award

Value: Up to $£ 10,000$, for a maximum of 1 year

Length of Study: 1 year

Application Procedure: Candidates should complete and submit an application form by the published deadline.

Funding: Trusts

Additional Information: Applicants must be based in the United Kingdom or the Republic of Ireland, although other members of the project team can be based overseas www.unigo.com/scholarships/by-major/dance-scholarships/ washington-american-indian-endowed-scholarship/1905

\section{For further information contact:}

Tel: (44) 2076115757

Email: PEgrants@wellcome.ac.uk

\section{Career Re-Entry Fellowships}

Purpose: This scheme is for postdoctoral scientists who have recently decided to recommence a scientific research career after a continuous break of at least 2 years.

Eligibility: The awards are open to individuals with a relevant connection to the European Economic Area (EEA). You should be a research scientist with at least 2 years' postdoctoral experience and intend to be based in a United Kingdom or Republic of Ireland organization. You must have had a continuous career break of at least 2 years and should have either a strong research track record (if applying for up to 4 years' support) or demonstrated the potential for a strong research career prior to your break (if applying for 2 years' support). A 2-year fellowship should provide sufficient training support to consolidate your potential. The proposed research should fall within the Wellcome Trust's normal funding remit. Resubmissions are not normally encouraged. If your application has been unsuccessful, please contact the Office for advice. You must have an eligible sponsoring laboratory in the United Kingdom or Republic of Ireland that will administer the fellowship for the duration of the award.

Level of Study: Professional development

Type: Fellowship

Value: It provides support that includes the fellow's salary, as determined by the host institution with an additional Trust enhancement, and Research expenses (consumables, animals, travel support to attend scientific meetings)

Length of Study: $2-4$ years

Application Procedure: A preliminary application form (Word $92 \mathrm{kB}$ ) should be completed and submitted by the published deadline. It should be sent electronically (as a Word document), with the requested accompanying information, to the appropriate funding stream at the Trust (see website). If successful, you will be shortlisted for interview.

Funding: Trusts

Additional Information: For further information visit www. wellcome.ac.uk/Funding/Biomedical-science/Funding-schemes/ Fellowships/Basic-biomedical-fellowships/wtd004380.htm, www.wellcome.ac.uk/funding/schemes/research-career-re-entryfellowships

\section{For further information contact:}

Tel: (44) 2076115757

Email: sciencegrants@wellcome.ac.uk

\section{Clinical PhD Programmes}

Purpose: This is a flagship scheme aimed at supporting the most promising medically qualified clinicians who wish to undertake rigorous research training.

Eligibility: You should have demonstrated the potential to pursue a career as an academic clinician. It is anticipated that many applicants will have already commenced their specialist training, but this is not essential.

Level of Study: Postgraduate, Research

Type: Grant

Value: The duration may vary from Programme to Programme, but each provides a clinical salary, $\mathrm{PhD}$ registration fees at United Kingdom/EU student rate, research expenses, 
contribution towards travel and contribution towards general training costs.

Frequency: Annual

Country of Study: Any country

Application Procedure: Students are recruited annually by the individual Programmes. Recruitment begins in the preceding January. If you are interested in applying you should contact the relevant Programme directly. Please see website for more details.

Closing Date: 6 March

Funding: Trusts

Additional Information: www.sanger.ac.uk/about/study/ phd-programmes/clinical-phd-programme

\section{For further information contact:}

Email: clinicalphd@wellcome.ac.uk

\section{Doctoral Studentships}

Purpose: This scheme enables scholars to undertake up to 3 years of full-time research on a history of medicine topic leading to a doctoral degree at a university in the United Kingdom or Republic of Ireland.

Eligibility: You should hold a Master's in the history of medicine or a Master's with strong emphasis on the history of medicine. The proposed project must be on a history of medicine topic. If specialist language skills are essential to undertake the research, a Master's in the language required may be acceptable (classical languages, Arabic, Chinese, etc.). Your application must be sponsored by a senior member of the department, unit or institute, or History of Medicine grant holder (current or former), who would supervise you if an award were made. Applications must be submitted through the host institution.

Level of Study: Postgraduate, Research

Value: Support is provided for up to 3 years, and includes: the student's stipend; a set amount to cover conference travel, research expenses and, where justified, the cost of overseas fieldwork; all compulsory university and college fees at the United Kingdom/Irish/Dutch home postgraduate student level; fees at the overseas rate will not be provided; institutions sponsoring candidates are expected to provide laptops and PCs as part of their postgraduate research-training infrastructure.

Length of Study: 3 years

Application Procedure: Preliminary applications should be made by email or post by the published deadline, and should include: a brief curriculum vitae with details of the Master's degree held; details of the research proposed (maximum of one page); a letter of support from the head of the department in which you will be working (this can be sent under separate cover); a letter of support from the supervisor.
Closing Date: 16 March

Funding: Trusts

Additional Information: www.wellcome.ac.uk/funding/ schemes/doctoral-studentships

\section{For further information contact:}

Tel: $\quad$ (44) 2076115757

Email: MHgrants@wellcome.ac.uk

\section{Four-year PhD Studentship Programmes}

Purpose: This is a flagship scheme aimed at supporting the most promising students to undertake in depth postgraduate training. Supporting specialized training provided in a range of important biomedical research areas: (1) Developmental biology and cell biology; (2) Genetics, statistics and epidemiology; (3) Immunology and infectious disease; (4) Molecular and cellular biology; (5) Neuroscience; (6) Physiological sciences; (7) Structural biology and bioinformatics.

Eligibility: You should be a student who has, or expects to obtain, a first- or upper-second-class honours degree or equivalent.

Level of Study: Postgraduate, Research

Type: Studentship

Value: A stipend, $\mathrm{PhD}$ registration fees at United Kingdom/ EU student rate, contribution towards laboratory rotation expenses in the first year, research expenses for years two to four, contribution towards travel and contribution towards transferable-skills training.

Length of Study: Support provided for 4 years

Application Procedure: Students are recruited annually by the individual Programmes for uptake in October each year. Recruitment begins in the preceding December. If you are interested in applying you should contact the relevant Programme directly. Please see website for details.

Closing Date: October

Funding: Trusts

Additional Information: www.wellcome.ac.uk/funding/ schemes/four-year-phd-programmes-studentships-basic-scie ntists

\section{For further information contact:}

Email:4yrphd@wellcome.ac.uk

\section{Innovator Awards}

Purpose: These awards support researchers who are transforming great ideas into healthcare innovations that could have a significant impact on human health. 
Eligibility: 1. Innovator Awards are open to researchers who are developing healthcare innovations that could have a major and measurable impact on human health. 2. Individuals and teams from not-for-profit and commercial organisations can apply. 3. Organisations can be of any size, based anywhere in the world (apart from mainland China).

Level of Study: Research

Type: Award

Value: Up to $£ 500,000$, or up to $£ 750,000$ for multidisciplinary collaborations.

Length of Study: 2 year

Frequency: Annual

Application Procedure: You must submit your application through the Wellcome Trust Grant Tracker (WTGT).

Funding: Trusts

\section{For further information contact:}

Gibbs Building, 215 Euston Road, London NW1 2BE, United Kingdom.

Tel: (44) 2076115757

Email: innovations@wellcome.ac.uk

\section{Intermediate Clinical Fellowships}

Purpose: This scheme is for medical, dental, veterinary or clinical psychology graduates who have had an outstanding start to their research career. It will enable successful candidates to continue their research interests at a postdoctoral level in an appropriate unit or clinical research facility.

Eligibility: The award is open to individuals with a relevant connection to the EEA. You should have previously undergone a period of research training and will have completed, or be about to complete, a higher degree. You should have completed general professional training as defined by the relevant college. 1. Medical and dental candidates should either have a National Training Number (NTN) or Certificate of Completion of Specialist Training (CCST) or equivalent. 2. Veterinary candidates should have a degree in veterinary medicine (e.g. BVSc, BVM\&S, BVMS, BVetMed, VetMB) and some experience in clinical practice and will have completed, or be about to complete, a higher research degree (preferably a $\mathrm{PhD}$ ). 3. GPs are advised to contact the office to clarify their eligibility. 4. Clinical Psychologists must have obtained a professional Doctorate-level qualification in Clinical Psychology accredited by the British Psychological Society.

Level of Study: Postgraduate, Research

Type: Fellowship

Value: Fellowships are for up to 4-5 years, depending on situation. They provide research expenses (consumables, travel, support to attend scientific meetings) and the fellow's salary, set by the host institution according to age and experience. Requests for specific items of equipment, where relevant, may be considered, and research or technical assistance may be requested. However, a laboratory appropriate to the research proposed should be selected, and the necessary facilities required for the proposed research must be available to the candidate. Funding for a period of research abroad may be requested if scientifically justified, and we provide appropriate allowances for fellows based overseas.

Frequency: Annual

Application Procedure: A preliminary application form should be completed and submitted at any time before the appropriate deadline. It should be sent electronically (as a Word document) to the appropriate funding stream at the Trust (see website). If your preliminary application is successful, you will be invited to submit a full application by the published deadline. This will be peer reviewed and considered by the relevant Funding Committee. Shortlisted candidates will subsequently be invited to attend for interview at the Trust.

Funding: Trusts

Additional Information: www.wellcome.ac.uk/funding/ schemes/intermediate-clinical-fellowships

\section{For further information contact:}

Tel: (44) 2076115757

Email: sciencegrants@wellcome.ac.uk

\section{Intermediate Fellowships in Public Health and Tropical Medicine}

Purpose: This scheme enables high-calibre, mid-career researchers from low- and middle-income countries to establish an independent research programme. Fellows must be based primarily in a low- and middle-income country. Research projects should be aimed at understanding and controlling diseases (either human or animal) of relevance to local, national or global health. This can include laboratory based molecular analysis of field or clinical samples, but projects focused solely on studies in vitro or using animal models will not normally be considered under this scheme.

Eligibility: Applications are only accepted in the Public Health and Tropical Medicine Interview Committee remit. This covers research on infectious and non-communicable diseases within the fields of public health and tropical medicine that is aimed at understanding and controlling diseases (either human or animal) of relevance to local, national or global health. You must be a national or legal resident of a low- and middle-income country and should be either 1. A graduate in a subject relevant to public health or tropical 
medicine (e.g. biomedical or social science, veterinary medicine, physics, chemistry or mathematics) with a $\mathrm{PhD}$ and 3-6 years' postdoctoral experience, or 2. A medical graduate with a higher qualification equivalent to membership of the United Kingdom Royal Colleges of Physicians (i.e. qualified to enter higher specialist training) or recognized as a specialist within a relevant research area, with 3-6 years' research experience. You must have a relevant high-quality publication record and show potential to become a future scientific leader. Applicants who do not have a $\mathrm{PhD}$ but who are educated to first degree or Master's level and have extensive research experience, as evidenced by their publication record, may be considered.

Level of Study: Postgraduate, Research

Type: Fellowship

Value: Fellowships are for up to 5 years (non-renewable) and provide support that includes: a basic salary for the fellow; research expenses (e.g. consumables, equipment, collaborative travel, research assistance, technical support); training costs where appropriate and justified; an inflation/flexible funding allowance and support to attend scientific meetings. Contributions to costs of the project which are directly incurred by the overseas institution may be provided.

Application Procedure: You must complete and submit a preliminary application form by the published deadline. The form should be emailed to phatic@wellcome.ac.uk

Funding: Trusts

Additional Information: For complete details please check the link www.wellcome.ac.uk/Funding/Biomedical-science/ Funding-schemes/Fellowships/Public-health-and-tropicalmedicine/wtd025883.htm www.successcds.net/Scholarships/ wellcome-trust-training-fellowships-in-public-health-andtropical-medicine.html

\section{For further information contact:}

Tel: (44) 2076115757

Email: sciencegrants@wellcome.ac.uk

\section{International Engagement Awards}

Purpose: To provide funding for innovative public or community engagement projects that explore biomedical research or health in Africa and Asia and to ensure science can be enjoyed and experienced as part of culture, entertainment and everyday life.

Eligibility: The scheme is open to a wide range of people, including media professionals, educators, science communicators, health professionals and researchers in bioscience, health, bioethics and history. Partnership projects (between different people and organizations, e.g. scientists and media professionals, ethicists and community workers) are welcomed. Applicants must be based in listed low- and middle- income countries or in the United Kingdom working with partners in the low- and middle-income countries. The activity must primarily take place in one or more low- and middleincome countries and the primary goal must be to involve participants or engage audiences located in low- and middleincome countries. Applicants from listed restructuring countries in Europe and Asia are not eligible. We can only accept applications in the English language but we welcome projects that bring together people from different backgrounds who speak diverse languages. All projects must involve engagement with health research. Projects dealing purely with development research not related to health are not eligible. Please note also, that the scheme is not intended to support standard delivery of health education and promotion which does not focus on health research or involve health researchers. Applicants must be affiliated to organizations or institutions. Organizations might include: media organizations, research centres or research groups, community-based development organizations, education organizations. The International Engagement Awards will not fund traditional scientist-led health research. We may consider an application for participatory health research. This is research in which participants are supported to own and shape a research process, setting their own research questions and directing the research process. This type of research should not look like a consultatory exercise or health education but should aim to be collaborative process of enquiry in which the analysis is conducted and findings can be used by all participating parties. This could lead into circular processes of research and action.

Level of Study: Research

Type: Award

Value: Up to $£ 30,000$ for projects lasting a maximum of 3 years.

Application Procedure: Please contact the International Engagement Awards office well in advance of the deadline to request an application form and to confirm the eligibility of your project.

Closing Date: 19 August

Funding: Trusts

Additional Information: www.wellcome.ac.uk/what-we-do/ directories/international-engagement-awards-people-funded

\section{For further information contact:}

Tel: (44) 2076115757

Email: PEgrants@wellcome.ac.uk

\section{International Training Fellowships}

Purpose: This scheme offers nationals of low- and middleincome countries the opportunity to receive training at postgraduate or postdoctoral level. 
Eligibility: 1. You're a national of a low- or middle-income country 2. Your proposed research focuses on a health priority in a low- or middle-income country 3 . You have sponsorship from an eligible host organisation in a low- or middle-income country apart from mainland China. 4. You must want to undertake a guided period of research so that you can consolidate your existing experience and explore new areas of research. 5. You must have a $\mathrm{PhD}$ and be an early-career researcher or have a degree in a relevant subject and some initial research experience or be a clinically qualified doctor (and be qualified to enter higher specialist training), vet, dentist or clinical psychologist, and have some initial research experience.

Level of Study: Postgraduate

Type: Fellowship

Value: Usually $£ 15,000$ to $£ 300,000$ for salary, fees and research expenses.

Length of Study: 3 year

Frequency: Annual

Application Procedure: You must submit your application through the Wellcome Trust Grant Tracker (WTGT).

Closing Date: 9 July

Funding: Trusts

\section{For further information contact:}

Gibbs Building, 215 Euston Road, London NW1 2BE, United Kingdom.

\section{Tel: (44) 2076115757}

\section{Investigator Awards}

Purpose: To support world-class researchers who are no more than 5 years from appointment to their first academic position, but who can already show that they have the ability to innovate and drive advances in their field of study.

Eligibility: To be eligible for an Investigator Award you must be based at an eligible higher education or research institution in the United Kingdom, Republic of Ireland or a low- or middle-income country. You should be employed in an established academic post: a permanent, open-ended or longterm rolling contract, salaried by your host institution. You are also eligible if you have a written guarantee of an established academic post at your host institution, which you will take up by the start of the award. If you are based in a low- or middleincome country in sub-Saharan Africa, South-east Asia or South Asia (with the exception of India - see below), you are eligible to apply if you fulfil the above eligibility criteria and are working within the Trust's broad science funding remit.

Level of Study: Research

Type: Award
Value: Awards may be small or large, typically up to $£ 3,000,000$, and lasting up to 7 years. The duration and costs you request should be clearly justified by your proposed research. Also, you should ensure that the scope of your proposal and the associated resources are appropriate for your career stage and research experience. The award covers the direct costs of carrying out the research, such as: research expenses; this may include research assistance, animals, equipment, fieldwork costs and funding for collaborative activity; travel and subsistence for scientifically justified visits; overseas allowances where appropriate.

Length of Study: Flexible duration, up to 7 years

Frequency: Annual

Application Procedure: The key stages of the application process are: submission of an Investigator Award application form; scientific peer review by one of the Trust's Expert Review Groups, which shortlist the candidates for interview; written peer review of shortlisted applications by external specialist referees, who will include members of the Trust's Peer Review College; selected unattributed referee comments will be fed back to candidates before interview; interview of shortlisted candidates by our Interview Panel. Application forms are available on eGrants, our electronic application system. Please refer to the Additional information for completing the Investigator Award form on eGrants, which provides an overview to help guide you through the application process.

Closing Date: 27 February

Funding: Trusts

Additional Information: The Trust has combined its New Investigator and Senior Investigator Award schemes to create a single type of Investigator Award, providing all who hold established posts in eligible organizations with the same opportunity to obtain funding www.wellcome.ac.uk/ funding/schemes/investigator-awards-science

\section{For further information contact:}

Email: sciencegrants@wellcome.ac.uk

\section{Learned Society Curation Awards}

Purpose: These awards support learned society publishers who want to explore new ways of signalling the significance of published research outputs in an open and transparent manner.

Level of Study: Research

Type: Award

Value: Up to $£ 200,000$

Length of Study: 3 year

Frequency: Annual

Application Procedure: You must submit your application through the Wellcome Trust Grant Tracker (WTGT). 
Closing Date: 20 April

Funding: Trusts

\section{For further information contact:}

Gibbs Building, 215 Euston Road, London NW1 2BE, United Kingdom.

Tel: (44) 2076115757

Email: openresearch@wellcome.ac.uk

\section{Master's Awards}

Purpose: This scheme enables scholars to undertake basic training in research and methods through a 1-year Master's course in medical history and humanities.

Eligibility: You should have a minimum of an excellent upper-second-class honours degree (or equivalent) in a relevant subject. Applications will not be considered from those who have already received support for their postgraduate studies from another funding body.

Level of Study: Postgraduate, Research

Type: Award

Value: The award is for 1 year, and includes the student's stipend; all compulsory university and college fees at the United Kingdom home postgraduate student level. Fees at the overseas rate will not be provided.

Frequency: Annual

Application Procedure: All enquiries about Master's Awards should be made directly to the relevant institution.

Closing Date: 1 May

Funding: Trusts

\section{For further information contact:}

Tel: (44) 2076115757

Email: MHgrants@wellcome.ac.uk

\section{Master's Fellowships in Public Health and Tropical Medicine}

Purpose: This scheme strengthens scientific research capacity in low- and middle-income countries, by providing support for junior researchers to gain research experience and high-quality research training at Master's degree level. Research projects should be aimed at understanding and controlling diseases (either human or animal) of relevance to local, national or global health. This can include laboratory based molecular analysis of field or clinical samples, but projects focused solely on studies in vitro or using animal models will not normally be considered under this scheme.
Eligibility: You should be: 1. A national or legal resident of a low- and middle-income country, and hold a first degree in subject relevant to tropical medicine or public health (clinical or non-clinical). 2. At an early stage in your career, with limited research experience, but have a demonstrated interest in or aptitude for research.

Level of Study: Postdoctorate, Postgraduate, Research Type: Fellowship

Value: This fellowship normally provides up to 30 months' support. A period of 12 months should normally be dedicated to undertaking a taught Master's course at a recognized centre of excellence, combined with up to 18 months to undertake a research project. While undertaking a Master's course, fellows will receive a stipend in accordance with the cost of living in the country in which he/she will be studying; travel costs and support for approved tuition fees. Master's training by distance learning is acceptable. Master's course fees will be paid according to the rate charged by the training institution.

Application Procedure: A completed application form should be submitted by the sponsor by the published deadline. The form should be emailed to phatic@wellcome.ac.uk

Closing Date: 2 March

Funding: Trusts

Additional Information: For complete details go to address www.wellcome.ac.uk/Funding/Biomedical-science/Fundingschemes/Fellowships/Public-health-and-tropical-medicine/ wtd025881.htm

\section{For further information contact:}

Tel: (44) 2076115757

Email: sciencegrants@wellcome.ac.uk

\section{Pathfinder Awards}

Purpose: This scheme, offering pilot funding to catalyse innovative early-stage applied research and development projects in areas of unmet medical need, has been expanded. It now funds discrete projects from applicants in the United Kingdom and Republic of Ireland as well as partnerships between academia and industry based anywhere in the world. Eligibility: Applications are welcome from academic and commercial organizations based in the United Kingdom or the Republic of Ireland. Applications from organizations and companies overseas will only be considered when applying in partnership. Check website for complete details.

Level of Study: Research

Type: Grant

Value: The average award amount is envisaged to be in the region of $£ 100,000$, but up to $£ 350,000$ will be considered in exceptional circumstances. 
Length of Study: 18 months

Frequency: Dependent on funds available

Application Procedure: You should contact us to confirm that your proposed application (and partnership, if appropriate), is eligible before submitting a full application form. After confirming that your application is eligible, you should complete the full application form (see 'Forms and guidance') and send it to innovations@wellcome.ac.uk

Closing Date: February

Funding: Trusts

Additional Information: www.wellcome.ac.uk/funding/ schemes/pathfinder-awards

\section{For further information contact:}

Email: innovations@wellcome.ac.uk

\section{Postdoctoral Research Training Fellowships for Clinicians}

Purpose: This is a flexible fellowship scheme to enable individuals to engage with areas of research that are new to them. It is for candidates who either undertook a $\mathrm{PhD}$ early in their career and now wish to refresh their research skills, or have recently completed a successful $\mathrm{PhD}$ and wish to explore a new research field or environment, to gain the skills that will help them answer their longer-term research vision.

Eligibility: The scheme may be suitable for clinicians who: are due to complete their higher degree or are no more than 2 years from the date of their $\mathrm{PhD}$ viva by the full application deadline; graduated with a $\mathrm{MB} / \mathrm{PhD}$ qualification or have achieved a high-quality $\mathrm{PhD}$ in a relevant subject, either during or prior to commencing their initial medical, veterinary or dental degree.

Level of Study: Postgraduate, Research

Type: Fellowship

Value: Awards are for 2-4 years, depending on whether or not you are planning to reintegrate into your clinical training programme. The total cost of a Fellowship would typically range from $£ 250,000$ to $£ 400,000$.

Frequency: Annual

Application Procedure: A preliminary application form should be completed and submitted at any time before the published deadline. It should be sent electronically (as a Word document) to Dr Lucy Bradshaw (see website for contact details). If your preliminary application is successful, you will be invited to submit a full application. This will be reviewed and if successful you will be shortlisted for interview.

Funding: Trusts

Additional Information: For more details see www.wellcome. ac.uk/Funding/Biomedical-science/Funding-schemes/
Fellowships/Clinical-fellowships/wtp052588.htm, www. wellcome.ac.uk/funding/schemes/postdoctoral-research-trainingfellowships-clinicians

\section{For further information contact:}

Tel: (44) 2076115757

Email: sciencegrants@wellcome.ac.uk

\section{Principal Research Fellowships}

Purpose: This is the most prestigious of our personal awards and provides long-term support for researchers of international standing. Successful candidates will have an established track record in research at the highest level.

Eligibility: You should have an established track record in research at the highest level. This award is particularly suitable for exceptional senior research scientists currently based overseas who wish to work in the United Kingdom or Republic of Ireland.

Level of Study: Postgraduate, Research

Type: Fellowship

Value: Awards are for 7 years in the first instance, and provide both a personal salary and research programme funding in full. After the first period of award, the fellowship will be subject to a competitive scientific review, which will subsequently occur on a rolling basis every 5 years

Length of Study: 7 years

Application Procedure: If you intend to apply you should contact us with a full curriculum vitae, preferably 18 months in advance of the desired award date. You may not apply for more than one Wellcome Trust fellowship scheme at any one time.

Funding: Trusts

Additional Information: The maximum duration of the awards is 3 years. The awards are full-time but can be tenable on a part-time basis if a case can be made that personal circumstances require this www.wellcome.ac.uk/funding/ schemes/principal-research-fellowships

\section{For further information contact:}

Tel: (44) 2076115757

Email: sciencegrants@wellcome.ac.uk

\section{Research and Development for Affordable Healthcare in India}

Purpose: The objective of this initiative is to fund translational research projects that will deliver safe and effective healthcare products for India, and potentially other markets, at affordable costs. A key feature of the scheme is that it 
encourages innovations that bring together researchers from both the public and private sectors to extend access to care to the greatest numbers of beneficiaries, without compromising on quality.

Eligibility: Awards will be agreed by Committee and governed by the terms and conditions, including Wellcome Trust Grant Conditions, funding terms for Affordable Healthcare. In addition there will be additional terms and conditions that will be negotiated under the funding agreement for the award with the applicant.

Level of Study: Research

Type: Award

Value: Awards will be made by way of funding agreements that will be negotiated on a case-by-case basis. The principles of the Wellcome Trust Grant Conditions will apply. The terms and conditions of funding will be discussed with applicants individually. Typically, the agreements will contain a provision for the appropriate sharing of benefits. The funds available will be ring-fenced for the specified programme of work. Neither working capital nor building or refurbishment expenditure will be provided. Funding will be released in tranches against the attainment of pre-agreed project milestones

Application Procedure: In the first instance interested applicants should contact Dr Shirshendu Mukherjee to discuss their interest in funding via the Affordable Healthcare Initiative. Alternatively, applicants may complete a concept note and mail this directly to Dr Shirshendu Mukherjee.

Closing Date: 31 January

Funding: Trusts

\section{For further information contact:}

Email: s.mukherjee@wellcome.ac.uk

\section{Research Career Development Fellowships in Basic Biomedical Science}

Purpose: To provide support for outstanding postdoctoral scientists based in academic institutions in the United Kingdom and Republic of Ireland (RoI).

Eligibility: You should have a relevant connection to the European Economic Area. You are expected to have science or veterinary qualifications and, at the preliminary application stage, should normally have between three and 6 years' research experience from the date of your doctoral degree (PhD viva). Due allowance will be given to those whose career has been affected for personal reasons. You must have made intellectual contributions to research that have been published in leading journals, and be able to demonstrate your potential to carry out independent research. The proposed research should fall within our normal funding remit. Resubmissions are not normally encouraged. If your application has been unsuccessful, please contact the Office for advice. You must have an eligible sponsoring host institution in the United Kingdom or Republic of Ireland (RoI) and an eligible sponsor who can guarantee space and resources for the tenure of any award.

Level of Study: Postdoctorate, Research

Type: Fellowship

Value: 1. A basic salary, as determined by the host institution, with an additional Wellcome Trust enhancement. 2. Research expenses, including research assistance if required (normally a graduate research assistant or technician; requests for additional research staff may be considered where fieldwork or clinical studies in a low- or middle-income country are proposed). 3. Overseas allowances where appropriate. 4. Travel and subsistence for scientifically justified visits of up to 1 year.

Length of Study: 5 years

Frequency: Annual

Application Procedure: A preliminary application form should be completed and submitted by the published deadline. It should be sent electronically (as a Word document), with the requested accompanying information, to the appropriate funding stream at the Trust (see website). If successful, you will be invited to submit a full application

Closing Date: 12 May

Funding: Trusts

Additional Information: www.wellcome.ac.uk/funding/ schemes/research-career-development-fellowships

\section{For further information contact:}

Tel: (44) 2076115757

Email: sciencegrants@wellcome.ac.uk

\section{Research Fellowships}

Purpose: Due to the multidisciplinary nature of research on the social and ethical aspects of biomedicine and healthcare, Research Fellowships may provide postdoctoral researchers with support to enable them to obtain research training, either in a new discipline or in a new aspect of their own field, e.g. a humanities scholar who wishes to be trained in social science. In such cases, the requested training must form a substantial component of the proposed research and should not normally be available via the standard funding routes, e.g. by learning new skills as a postdoctoral researcher on a project grant. The requested training should also include methodologies and skills that are new to the applicant. Research training provision can include participation in taught courses, and periods spent in other research groups gaining practical, technical or other skills for introduction to the sponsor's or individual's own group. 
Eligibility: You are eligible to apply if you are a postdoctoral scholar who is not in a tenured or otherwise long-term established post. Fellowships must be held at a United Kingdom, Irish or low- or middle-income country institution. You will also be expected to have been awarded your PhD before you are eligible to apply. Applications from candidates who are still awaiting their viva by the time of the full application will not normally be accepted.

\section{Level of Study: Research}

Type: Fellowship

Value: An award will not normally exceed $£ 250,000$, exclusive of any standard Wellcome Trust allowances. Fellowships provide a salary, plus appropriate employer's contributions. Essential research expenses, including travel and fieldwork, are available, as is a set amount for travel to conferences, seminars and other meetings of a scholarly nature.

Length of Study: 3 years

Application Procedure: Preliminary applications should be made in writing, and include: a brief curriculum vitae and full publication list; details of research proposed (maximum of 1 page); a letter of support from the head of department in which you will be working; the approximate cost of the proposal, broken down into equipment and project running expenses.

Funding: Trusts

\section{For further information contact:}

Tel: (44) 2076115757

Email: MHgrants@wellcome.ac.uk

\section{Research Fellowships in Humanities and Social Science}

Purpose: This scheme supports postdoctoral researchers in health-related humanities and social sciences who do not hold established academic posts.

Level of Study: postdoctoral

Type: Fellowship

Value: Salary and research expenses covered.

Length of Study: 3 year

Frequency: Annual

Application Procedure: You must submit your application through the Wellcome Trust Grant Tracker (WTGT).

Closing Date: 10 September

\section{For further information contact:}

Gibbs Building, 215 Euston Road, London NW1 2BE, United Kingdom.

Tel: (44) 2076115757

Email: hss@wellcome.ac.uk.

\section{Research Training Fellowships}

Purpose: Provide support for medical, dental, veterinary and clinical psychology graduates who have little or no research training, but who wish to develop a long-term career in academic medicine.

Eligibility: The fellowship is open to individuals with a relevant connection to the European Economic Area (EEA) for fellowships to be held in a United Kingdom or Republic of Ireland institution. Non-United Kingdom candidates should contact the office for advice before submitting an application. 1. Medical graduates must have passed the relevant exam for their specialty, e.g. MRCP, MRCS, MRCOphth/FRCOphth Part 1, MRCPsych, MRCOG Part 1, MRCPCH, FRCA Part 1. GPs are advised to contact the office to clarify their eligibility. 2. Dental candidates must have obtained MFD, MFDS, MGDS, MFGDP or equivalent. 3. Veterinary candidates should have a degree in veterinary medicine (e.g. BVSc, BVM\&S, BVMS, BVetMed, VetMB) and some experience in clinical practice. An intercalated degree is desirable, but not essential. 4. Clinical psychology candidates must have obtained a professional Doctorate-level qualification in Clinical Psychology accredited by the British Psychological Society before taking up the award. Candidates are advised to contact the office to clarify their eligibility. You are expected to undertake a high-quality research project that balances the provision of training with the opportunity to advance knowledge in a given area. A project based solely on a systematic review of a particular area is not suitable, unless it includes a significant element of methodological innovation.

Level of Study: Postgraduate, Research

Type: Fellowship

Value: Fellowships are normally for $2-3$ years. In exceptional cases a fellowship may be for up to 4 years for those who wish to undertake a relevant Master's training or diploma course. All training requests must be fully justified in the application. Fellowships provide research expenses (consumables, travel, and support to attend scientific meetings) and a fellow's salary, set according to age, experience and our policy on enhancement.

Length of Study: $2-3$ years

Application Procedure: Application form is available from the website.

Funding: Trusts

\section{For further information contact:}

Tel: (44) 2076115757

Email: sciencegrants@wellcome.ac.uk

\section{Science Media Studentships}

Purpose: We aim to increase the crossover between science and the media and to enable bright, articulate and motivated scientists to explore a career in the broadcast industry. 
Eligibility: Applicants should be PhD-level biomedical scientists wishing to explore a career in the broadcast, games and film industries. Applicants must have a $\mathrm{PhD}$ or equivalent, some experience of science communication, and a demonstrable aptitude for working with TV, radio, film or games.

Level of Study: Postdoctorate, Research

Type: Studentship

Value: Awards will pay for tuition costs plus a grant to cover basic living expenses for the duration of the studentship.

Frequency: Annual

Application Procedure: Application is through the Imperial College website.

Closing Date: 26 February

Funding: Trusts

Additional Information: www.wellcome.ac.uk/news/ science-media-studentships-call-applications-open

\section{For further information contact:}

Tel: $\quad$ (44) 2075948753

Email: liam.watson@imperial.ac.uk

\section{Seeding Drug Discovery}

Purpose: To facilitate early-stage small-molecule drug discovery. The awards help applicants with a potential drug target or new chemistry embark on a programme of compound discovery and/or lead optimization.

Level of Study: Research

Type: Award

Value: Early-stage drug discovery projects are able to apply for funding for up to 2 years to facilitate screening of chemical compounds to identify one or more lead series of molecules. Late-stage projects, where a lead compound has already been identified, are able to apply for funding for up to 4 years, to support lead optimization and preclinical development through to clinical trials.

Application Procedure: A preliminary application form should be completed and returned to Technology Transfer by the published deadline. Applications will be considered at one of the two Seeding Drug Discovery Committee meetings in each 12-month period. Successful applicants will be shortlisted and invited to complete a full application.

Funding: Trusts

Additional Information: www.wellcome.ac.uk/what-wedo/directories/seeding-drug-discovery-projects-funded

\section{For further information contact:}

Tel:

(44) 2076115757

Fax: (44) 2076118857

Email: innovations@wellcome.ac.uk

\section{Senior and Intermediate Research Fellowship for International Students}

Purpose: The aim of the fellowship is to supports outstanding researchers of any nationality, either medically qualified or science graduates, who wish to pursue a research career in an academic institution in India.

Eligibility: Applicants of any nationality are eligible to apply for the fellowship. Applicants must be a basic science/veterinary researchers with $4-15$ years of post-PhD research experience. Applicants must be fluent in English.

Type: Research

Value: The fellowship has the tenure of five years and provides: The Fellow's personal support. Research expenses, including research assistance if required (normally funding for four research staff may be requested). The total award for a Senior Fellowship typically includes the costs requested by the applicant as well as the set contributions by the India Alliance. For further details, see costing policies. Costs requested by the applicant must be commensurate with their research proposal and should be fully justified in the full application. Inadequate justifications may result in costs being revised. Time permitted for non-research related activity during the fellowship is normally restricted to a maximum of eight hours each week.

Study Establishment: Fellowship is awarded to support biomedical research that is relevant to human and animal welfare.

Country of Study: India

Application Procedure: See the website

Closing Date: 15 January

Additional Information: For more details please visit the website www.scholarship-positions.com/senior-intermediateresearch-fellowship-for-international-students-india/2018/01/ 02/, www.scholarshipsads.com/india-senior-intermediate-rese arch-fellowship-international-students-2018/

\section{For further information contact:}

Email: info@wellcomedbt.org

\section{Senior Fellowships in Public Health and Tropical Medicine}

Purpose: This scheme supports outstanding researchers from low- and middle-income countries to establish themselves as leading investigators at an academic institution in a low- and middle-income country location. This fellowship is the most senior of a series of career awards aimed at building sustainable capacity in areas of research that have the potential for increasing health benefits for people and their livestock in low- and middle-income countries. Research projects should be aimed at understanding and controlling diseases (either 
human or animal) of relevance to local, national or global health.

Eligibility: Candidate must be a graduate in a subject relevant to public health or tropical medicine (for example; biomedical or social science, veterinary medicine, physics, chemistry or mathematics) with a $\mathrm{PhD}$ and at least 5 years' postdoctoral experience, or a medical graduate with a higher qualification equivalent to membership of the United Kingdom Royal College of Physicians (i.e. qualified to enter higher specialist training), or be recognized as a specialist within a relevant research area, and have at least 5 years' research experience.

Level of Study: Postgraduate, Research

Type: Fellowship

Value: A basic salary; research expenses (e.g. consumables, equipment, collaborative travel, research assistance, technical support), training costs where appropriate and justified; an inflation/flexible funding allowance and support to attend scientific meetings; and contributions to costs of the project that are directly incurred by the overseas institution may also be provided.

Length of Study: Up to 5 years

Application Procedure: You are required to complete and submit a preliminary application form by the published deadline. The form should be emailed to phatic@wellcome.ac.uk Funding: Trusts

Additional Information: Overseas allowances will be provided for periods of training or collaborative research spent outside the home institution country, where appropriate. Research-dedicated costs (excluding salary costs) should not exceed $£ 100,000$ per year www.advance-africa.com/ Fellowships-in-Public-Health-and-Tropical-Medicine.html

\section{For further information contact:}

Tel: (44) 2076115757

Email: sciencegrants@wellcome.ac.uk

\section{Senior Research Fellowships in Basic Biomedical Science}

Purpose: To provide support for outstanding postdoctoral scientists based in academic institutions in the United Kingdom and Republic of Ireland (RoI).

Eligibility: The fellowship is open to individuals with a relevant connection to the EEA. You should have between 5 and normally 10 years' research experience (from the date of your viva to the date of your preliminary application) at postdoctoral level, or veterinary equivalent, and have a substantial record of publications in your chosen area of research in leading international journals. Candidates that do not hold an established post may apply to remain in their current laboratory, to return to one where they have worked before or to move to a new laboratory in the United Kingdom or Republic of Ireland. Candidates that hold an established post are not eligible to apply for a fellowship to be held at their current employing institution. However, we are willing to consider a preliminary application where a candidate wishes to move institution and is able to make an appropriate justification for the move. The Trust does not normally accept resubmissions of full applications for its fellowships. Please contact the Office for further advice. You must have an eligible sponsor and host institution in the United Kingdom or Republic of Ireland who can guarantee space and resources for the tenure of the award.

Level of Study: Postdoctorate, Research

Type: Fellowship

Value: The fellowship is for 5 years in the first instance, and provides a basic salary, as determined by the host institution (normally up to $£ 55,000$ per year) with an additional Trust supplement of $£ 12,500$ per year; the essential costs of the research programme (e.g. consumables, equipment, research assistance, overseas allowances, collaborative travel and subsistence); an inflation and Flexible Funding Allowance; and support to attend scientific meetings.

Frequency: Annual

Application Procedure: A preliminary application form should be completed and submitted electronically (as a Word document) to the relevant funding stream (see website) no later than the published deadline. Full application forms will usually be sent to shortlisted candidates within 1 month of the preliminary deadline. In the full application, if invited, the host institution will be required to confirm that it will support a successful renewal of the fellowship under the shared funding arrangement for the full period of any renewal. Funding: Trusts

Additional Information: Refer to the website www.wellcome. ac.uk/funding/biomedical-science/funding-schemes/fellowships/ basic-biomedical-fellowships/wtd004442.htm

\section{For further information contact:}

Tel: (44) 2076115757

Email: sciencegrants@wellcome.ac.uk

\section{Senior Research Fellowships in Clinical Science}

Purpose: This scheme provides support for clinical investigators to further develop their research potential and to establish themselves as leading investigators in clinical academic medicine.

Eligibility: You must have a relevant connection to the EEA. If you are a non-United Kingdom candidate, please contact the Office for advice before submitting a preliminary application. You should be a clinical scientist 
with a medical, dental, veterinary or clinical psychology qualification and will normally have no more than 15 years' clinical and research experience from the date of your first medical, dental, veterinary or British Psychological Societyaccredited psychology qualification. (Due allowance will be given to those whose career has been affected by a late start or interruption for personal/family reasons.) Successful candidates will have made significant progress towards establishing themselves as independent clinical investigators. A research degree $(\mathrm{PhD} / \mathrm{MD})$, together with evidence of advanced (postdoctoral) research training (typically at least $3-5$ years), is expected. They will have published consistently in their chosen area of research, placing substantive papers in leading journals. Candidates will not normally hold a tenured academic post in a university in the United Kingdom or Republic of Ireland, or a consultant post in the NHS.

Level of Study: Postgraduate, Research

Type: Fellowship

Value: The fellowship is for 5 years in the first instance, and provides: a basic salary, as determined by the host institution; research expenses; an inflation allowance and support to attend scientific meetings; provision for public engagement cost.

Frequency: Annual

Application Procedure: A preliminary application form should be completed and submitted by the published deadline. It should be sent electronically (as a Word document), with the requested accompanying information, to the appropriate funding stream at the Trust (see website). Incomplete or incorrectly completed forms will not be accepted. Faxed applications will not be accepted. Please do not send any additional material. You will be notified in writing of your success, or otherwise, in reaching the next round of the competition. In some instances, we may recommend that candidates apply for an Intermediate Clinical Fellowship.

Funding: Trusts

\section{For further information contact:}

Tel: (44) 2076115757

Email: sciencegrants@wellcome.ac.uk

\section{Short-term Research Leave Awards for Clinicians and Scientists}

Purpose: This scheme enables clinicians, scientists and other healthcare professionals to undertake up to 6 months (FTE) of research at a centre or department with academic expertise in medical humanities, to explore the wider determinants and contexts of their own medical and scientific work.

Eligibility: You should be a scientist, clinician or healthcare professional holding an established post to which you would return on completion of the award. You must be resident in the
United Kingdom or Republic of Ireland. You should have a record of publication in medical or scientific journals.

Level of Study: Research

Type: Award

Value: We will provide the salary of a locum or replacement lecturer for the duration of the award, and a set amount for travel to conferences.

Length of Study: Up to 6 months

Application Procedure: You should submit a preliminary application in writing, including: a brief curriculum vitae, a full publication list and confirmation that your personal support is from the Higher Education Funding Council; details of the research proposed (maximum one page); details of hours spent on teaching and administration; the approximate cost of the proposal, broken down into staff salaries, equipment and running expenses.

Closing Date: 23 January

Funding: Trusts

\section{For further information contact:}

Tel: (44) 2076115757

Email: MHgrants@wellcome.ac.uk

\section{Sir Henry Wellcome Postdoctoral Fellowships}

Purpose: To provide a unique opportunity for the most promising newly qualified postdoctoral researchers to make an early start in developing their independent research careers, working in the best laboratories in the United Kingdom and overseas.

Eligibility: These awards are open to individuals with a relevant connection to the European Economic Area. You must be in the final year of your PhD studies or have no more than 1 year of postdoctoral research experience from the date of your $\mathrm{PhD}$ viva to the full application submission deadline (e.g. if the full deadline is in February, your viva should not have occurred prior to last February). Time spent outside the research environment will be taken into consideration. You must have an eligible sponsoring institution in the United Kingdom or Republic of Ireland that will administer the fellowship for the full duration of the award.

Level of Study: Postdoctorate, Research

Type: Fellowships

Value: 4 year full-time fellowship. Provides an award of $£ 250,000$.

Length of Study: 4 years

Frequency: Annual

Application Procedure: You should complete and submit a preliminary application form by the published deadline. It should be sent electronically (as a Word document), with the requested accompanying information, to the relevant funding 
stream at the Trust. Your preliminary application will be assessed within 4 weeks of the submission deadline. If successful, you will be invited to submit a full application. Your full application will be peer reviewed by the relevant Funding Committee and, if successful, you will be shortlisted for interview.

Funding: Trusts

Additional Information: www.wellcome.ac.uk/funding/ schemes/sir-henry-wellcome-postdoctoral-fellowships

\section{For further information contact:}

Tel: (44) 2076115757

Email: sciencegrants@wellcome.ac.uk

\section{Strategic Awards in Biomedical Science}

Purpose: Strategic awards provide flexible forms of support to excellent research groups with outstanding track records in their field.

Eligibility: Applications will be considered from principal applicants who meet our eligibility criteria and are recognized international leaders in their field.

Level of Study: Research

Type: Award

Value: It provides equipment, support staff, consumables, training programmes, networking, biological, clinical or epidemiological research resources. Limited capital building or refurbishment essential to the programme can also be requested.

Length of Study: Awards are normally for 5 years

Application Procedure: You (prospective applicant) are required to submit a preliminary application, which should include the following information: 1. Your track record, you must complete the curriculum vitae pages (these are questions 14 and 15 from the standard project grant application form); 2. High-level aims and objectives, and how the proposal addresses the strategic challenges in the Wellcome Trust's Strategic Plan (maximum of two pages); 3. Key targets, milestones and management structures, if appropriate (maximum of two pages); 4. Duration of support requested and outline costings broken down into main headings (e.g. staff, equipment); 5. A statement from the head of the institution, indicating how the proposal fits within the context of the institution's strategic vision and what financial commitment the institution will make to the group if the application is successful. If your preliminary application is successful, you will be invited to submit a full application. The relevant form will be provided at this time.

Funding: Trusts

Additional Information: www.wellcome.ac.uk/what-wedo/directories/science-strategic-awards-people-funded

\section{For further information contact:}

Tel: (44) 2076115757

Email: sciencegrants@wellcome.ac.uk

\section{The Hub Award}

Purpose: The Hub Award brings researchers and creative professionals together at Wellcome Collection to work as a collaborative residency.

Type: Award

Value: Flexible funding, up to $£ 1$ million

Length of Study: 1 to 2 year

Frequency: Annual

Application Procedure: You must submit your application through the Wellcome Trust Grant Tracker (WTGT).

Closing Date: 20 February

\section{For further information contact:}

Gibbs Building, 215 Euston Road, London NW1 2BE, United Kingdom.

Tel: (44) 2076115757

\section{Training Fellowships in Public Health and Tropical Medicine}

Purpose: This scheme provides researchers from low- and middle-income countries-who are at an early stage in the establishment of their research careers-with opportunities for research experience and high-quality research training in public health and tropical medicine. Research projects should be aimed at understanding and controlling diseases (either human or animal) of relevance to local, national or global health. This can include laboratory-based molecular analysis of field or clinical samples, but projects focused solely on studies in vitro or using animal models will not normally be considered under this scheme.

Eligibility: Applications are only accepted in the Public Health and Tropical Medicine Interview Committee remit. This covers research on infectious and non-communicable diseases within the fields of public health and tropical medicine that is aimed at understanding and controlling diseases (either human or animal) of relevance to local, national or global health. You must be a national or legal resident of a low- and middle-income country and should be either: 1. A graduate in a subject relevant to public health or tropical medicine (e.g. biomedical or social science, veterinary medicine, physics, chemistry or mathematics) with a $\mathrm{PhD}$ and no more than 3 years' postdoctoral experience, or 2. A medical graduate with a higher qualification equivalent to membership 
of the United Kingdom Royal Colleges of Physicians (i.e. qualified to enter higher specialist training) and some initial research experience. Applicants may also apply if they do not have a PhD, but have a clinical, basic or Master's degree and some initial research experience, with the expectation that they will register for a $\mathrm{PhD}$.

Level of Study: Postgraduate, Research

Type: Fellowship

Value: Usually $£ 15,000$ to $£ 300,000$ for salary, fees and research expenses.

Length of Study: 3 years

Application Procedure: You are required to complete and submit a preliminary application form by the published deadline. The form should be emailed to phatic@wellcome.ac.uk Closing Date: 9 July

Funding: Trusts

Additional Information: www.scholarshipportal.com/schol arship/wellcome-trust-training-fellowships-in-public-healthand-tropical-medicine

\section{For further information contact:}

Tel: (44) 2076115757

Email: sciencegrants@wellcome.ac.uk

\section{Translation Fund}

Purpose: Translation Awards are response-mode funding designed to bridge the funding gap in the commercialisation of new technologies in the biomedical area.

Eligibility: Projects must address an unmet need in healthcare or in applied medical research, offer a potential new solution, and have a realistic expectation that the innovation will be developed further by the market. Institutions: eligible institutions are not-for-profit research institutions, including those funded by the Medical Research Council, Cancer Research United Kingdom, and Biotechnology and Biological Sciences Research Council, in the United Kingdom. Institutions are normally required to sign up to a short funding agreement and the Grant Conditions. Companies: we are able to use our charitable monies to fund commercial companies to meet our charitable objectives through programme-related investment (PRI). For further details please refer to our policy on PRI. Companies will normally be expected to sign up to specific terms relating to the scheme. Overseas organizations: United Kingdom organizations may contract or collaborate with overseas organizations. Although overseas organizations are not eligible for Translation Awards, some proposals may be invited for consideration as a Strategic Translation Award (including Seeding Drug Discovery). Overseas organizations should contact Technology Transfer staff about their proposed project in the first instance. Principal applicants and coapplicants: applicants should normally hold a position of responsibility within the eligible organization and be able to sign up to or comply with the conditions or terms of an award. In addition, postdoctoral research assistants-whether seeking their own salary as part of the grant proposal, funded by the Wellcome Trust on another grant, or funded by another agency-are eligible for coapplicant status if they make a significant contribution to a research proposal and have agreement from their funding agency. Other eligibility information: Disciplines outside biomedicine - researchers from disciplines outside biomedicine can apply providing the application of research is designed to facilitate or meet a need in healthcare. For example, the application of physics, chemistry, computing, engineering and materials science to the development of medical products is entirely appropriate. Healthcare need in an area that is not commercially attractive. We are committed to the translation of research into practical healthcare benefits across the full spectrum of disease. Disease areas neglected by industry because of the lack of a return on investment pose a particular problem, but imaginative ways forward can sometimes be developed (e.g. public-private partnerships such as the Medicines for Malaria Venture). Intellectual property rights (IPR)/publications - if there are any restrictions on IPR or publications arising from your research, you must provide a written statement that details them. Restrictions on intellectual property may affect your eligibility to apply to the Trust. Please refer to our Grant Conditions.

\section{Level of Study: Research}

Type: Award

Value: The important criterion is to develop the innovation to the point at which it can be adopted by another party. Providing it is adequately justified, modest equipment purchase and maintenance costs may be included in a Translation Award application. Building or refurbishment expenditure will not normally be considered. Applications may not include requests for academic institutional overheads. If you hold a tenured university post, you may not re-charge your salary (in full or part) to a Translation Award.

Application Procedure: A preliminary application form must be completed and sent to Technology Transfer by the published deadline. Preliminary applications are subject to a triage for shortlisting for the full application stage. Applications will be considered by the Technology Transfer Challenge Committee (TTCC), which meets twice a year. Full applications will be invited following the triage meeting. Shortlisted applicants will be invited to submit a full application and will be subject to international peer review and due diligence. Applicants will be expected to make a presentation on their proposal to the TTCC. Unless otherwise advised, this will be at the next scheduled meeting of the TTCC.

Funding: Trusts 
Additional Information: www.erc-online.eu/financialsupport/translation-fund/

\section{For further information contact:}

Tel: $\quad$ (44) 2076115757

Fax: (44) 2076118857

Email: innovations@wellcome.ac.uk

\section{Translational Medicine and Therapeutics Programmes}

Purpose: This flagship scheme established four high-quality integrated research training programmes for clinicians in translational medicine and therapeutics. The programmes have been developed around a unique partnership between academic and industrial partners. Support for the programmes has been provided to the host institutions by GlaxoSmithKline, Wyeth Research, Roche, AstraZeneca, Sanofi-Aventis, Sirtris Pharmaceuticals and PTC Therapeutics.

Eligibility: You should have demonstrated the potential to pursue a career as an academic clinician. It is anticipated that many applicants will have already commenced their specialist training, but this is not essential.

Level of Study: Postgraduate, Research

Value: Includes a clinical salary, $\mathrm{PhD}$ registration fees at United Kingdom/EU rate, research expenses, contribution towards travel, and a contribution towards training costs.

Length of Study: Support varies

Frequency: Annual

Application Procedure: If you are interested in applying you should contact the relevant programme. Please see website for details.

Closing Date: October

Funding: Trusts

\section{For further information contact:}

Email: j.williams@wellcome.ac.uk

\section{University Awards}

Purpose: This scheme allows universities to attract outstanding research staff by providing support for up to 5 years, after which time the award holder takes up a guaranteed permanent post in the university. A monograph and other substantial publications are expected to result from an award, so teaching and other non-research commitments are expected to be minimal during the period of full Wellcome Trust support.

Eligibility: You must be nominated by your prospective head of department and have an undertaking from the head of the institution, vice-chancellor, principal or dean that your personal support will be taken over by the institution at the end of the award. Support is normally available only at lecturer level, although in exceptional cases awards to senior-lecturer level may be possible.

Level of Study: Research

Type: Award

Value: Up to 5 years' support is available, providing your full salary for 3 years, $50 \%$ in the fourth year and $25 \%$ in the fifth year. Travel expenses to attend meetings are provided for 5 years, but research expenses are provided for the first 3 years of the award only.

Application Procedure: Initial enquiries about the scheme may be made by you (the potential candidate) or a department in an institution. These enquiries should be followed by a preliminary application from you by email or post including an explicit statement from the head of the institution, vicechancellor or dean demonstrating the institution's commitment to the history of medicine field, and a statement confirming that the institution will provide $50 \%$ salary costs in year four, $75 \%$ in year 5 and full salary thereafter; curriculum vitae and full publication list; an outline of no more than two pages of the proposed project; a letter of support from the head of department, including a statement on your expected teaching/administrative load for the 5 -year period (this can be sent by separate cover); the approximate cost of the proposal, broken down into your salary, equipment and project running costs.

Funding: Trusts

Additional Information: www.studentaffairs.ku.edu/ university-awards

\section{For further information contact:}

Tel: (44) 2076115757

Email: MHgrants@wellcome.ac.uk

\section{Wellcome Trust and NIH Four-Year PhD Studentships}

Purpose: This scheme provides opportunities for the most promising postgraduate students to undertake international, collaborative four-year $\mathrm{PhD}$ training based in both a United Kingdom/Republic of Ireland (RoI) academic institution and the intramural campus of the National Institutes of Health at Bethesda (Maryland, United States of America).

Eligibility: You should be a United Kingdom/European Economic Area (EEA) national with (or be in your final year and expected to obtain) a first- or upper-second-class honours degree or an equivalent EEA graduate qualification. You must have: 1. A suitable doctoral supervisor at an eligible academic host institution in the United Kingdom or Republic of Ireland. The host institution must be able to confer doctoral 
degrees; 2. A suitable supervisor at a NIH institute. The NIH supervisor should hold a tenured or tenured-track position for the proposed period of the award and should be willing to provide funding for the student whilst at the NIH.

Level of Study: Doctorate, Research

Type: Studentship

Value: The studentship is awarded for 4 years with support provided by the Wellcome Trust (in the United Kingdom/ Republic of Ireland) and the NIH (in the United States of America). Our funding will provide support for the student's stipend, $\mathrm{PhD}$ fees, college fees (if required) and a contribution towards research costs.

Length of Study: 4 year

Frequency: Annual

Application Procedure: The application form should be completed and submitted by the closing date. An electronic copy (as a Word document) should be emailed to wtnih@wellcome.ac.uk

Funding: Trusts

\section{For further information contact:}

Wellcome Trust-NIH PhD Studentships, Wellcome Trust, Gibbs Building, 215 Euston Road, Bloomsbury, London NW1 2BE, United Kingdom.

Email: wtnih@wellcome.ac.uk

\section{Wellcome Trust-POST Fellowships in Medical History and Humanities}

Purpose: This scheme enables a $\mathrm{PhD}$ student or junior fellow funded through the Wellcome Trust Medical History and Humanities (MHH) programme to undertake a 3-month fellowship at the Parliamentary Office of Science and Technology (POST).

Eligibility: Applicants should be in the second or third year of their $\mathrm{PhD}$ or in the first year of a fellowship funded by the MHH Programme. POST is a strictly non-partisan organization. Wellcome Trust-POST Fellows will be required to abstain from any lobbying or party political activity, and generally uphold the principles of parliamentary service, including a commitment to confidentiality, during their time with the Office. All provisionally selected candidates must sign a declaration to this effect. They must also receive security clearance from the parliamentary security authorities as a condition of finally taking up the fellowship.

Level of Study: Postdoctorate, Research

Type: Fellowship

Value: The successful applicant will receive a fully funded 3-month extension to their $\mathrm{PhD}$ or fellowship award. While placements typically last 3-months, they may be extended under exceptional circumstances. If the successful applicant is not within reasonable daily travelling distance to POST in London, the Wellcome Trust will consider paying travel and accommodation costs up to a maximum of $£ 2,000$.

Frequency: Annual

Application Procedure: An application should include the application form, your curriculum vitae, a letter of support from your sponsor/supervisor and a summary of a proposed topic for a POST publication. The summary should be no longer than 1,000 words and should demonstrate: why you think this subject would be of particular parliamentary interest; how the training you have received and your research to date will enable you to carry out this work; your ability to write in a style suitable for a parliamentary (rather than an academic) audience.

Closing Date: 23 November

Funding: Trusts

Additional Information: Check website for more details www.studentaffairs.ku.edu/university-awards

\section{For further information contact:}

Tel: (44) 2076115757

Email: MHgrants@wellcome.ac.uk

\section{Wells Mountain Foundation}

25 Main Street, Bristol, VT 05443, United States of America.

Tel: $\quad$ (1) 8773186116

Website: www.wellsmountaininitiative.org/

WMF is a non-profit, tax-exempt charity qualified of the US Internal Revenue Code. Wells Mountain Foundation has as its focus education, which they believe is the key building block to success in all other endeavors, literacy, the essential tie to the knowledge contained in the written word, and community, the core entity, just beyond the family, critical to building a compassionate and effective society.

\section{Woodcock-Munoz Foundation Empowerment Through Education Scholarships}

Purpose: The Foundation believes in the power and importance of community service; therefore, all scholarship participants are required to volunteer for a minimum of 100 hours a year.

Eligibility: The requirements are: 1 . Successfully completed a secondary education, with good to excellent grades. 2 . Is 
35 or under on March 1, 2021. 3. Will be studying in his or her country or another country in the developing world. 4. Is pursuing his or her first bachelor's degree or diploma. 5 . Will be enrolled in a program of study that will benefit the community and contribute to the continued growth and advancement of his or her home country. 6. Plans to live and work in his or her own country after graduation. 7. Has demonstrated his or her commitment to giving back and has volunteered prior to applying. 8. May have some other funds available for his or her education, but will not be able to go to pursue his or her tertiary degree without financial assistance. Level of Study: Graduate

Type: Scholarship

Value: Average of US $\$ 1,500$ for tuition and fee, books and materials.

Frequency: Annual

Country of Study: United States of America

Application Procedure: 1. You will be redirected to a portal where you will be asked to create a free account (username and password), fill out information and upload documents. 2 . We strongly suggest that you apply online as it will provide you with the opportunity to save your work and return multiple times. You will also guarantee that your application, once submitted online, will be received and reviewed.

Closing Date: 1 March

Funding: Private

Additional Information: Applications that arrive after March 1, 2021 will not be reviewed. This means that you must allow at least three weeks to mail your application to us from abroad. Only send one completed application. Incomplete or additional mailings with supporting documents will be discarded.

\section{Wenner-Gren Foundation for Anthropological Research}

655 Third Avenue, 23rd Floor, New York, NY 10017, United States of America.

Tel: $\quad$ (1) 2126835000

Email: inquiries@wennergren.org

Website: www.wennergren.org

The Wenner-Gren Foundation for Anthropological Research, Inc. is a private operating foundation dedicated to the advancement of anthropology throughout the world. Located in New York City, it is one of the major international funding sources for anthropological research and is actively engaged with the anthropological community through its varied grant, fellowship, conference, and capacity building programs.

\section{Hunt Postdoctoral Fellowships}

Purpose: To support the writing-up of already completed research.

Eligibility: Applicants must have a $\mathrm{PhD}$ or equivalent at the time of application and must have received a $\mathrm{PhD}$ or equivalent within 10 years of the application deadline. Qualified scholars are eligible without regard to nationality, institutional, or departmental affiliation although preference is given to applicants who are untenured or do not yet have a permanent academic position.

Level of Study: Postdoctorate

Type: Fellowship

Value: Up to US $\$ 40,000$

Frequency: Annual

Country of Study: Any country

Application Procedure: Applications can be downloaded from the website and must be submitted online.

No. of awards offered: 89

Closing Date: 1 May

No. of awards given last year: 9

No. of applicants last year: 89

Additional Information: Qualified scholars are eligible without regard to nationality or institutional affiliation www. wennergren.org/programs/hunt-postdoctoral-fellowships

\section{Wharton School}

Vance Hall, Suite 111, 3733 Spruce Street, Philadelphia, PA 19104-6340, United States of America.

Tel:

$$
\text { (1) } 2158986183
$$

Email: mba.admissions@wharton.upenn.edu Website: www.wharton.upenn.edu/mba/catalog

The Wharton School of the University of Pennsylvania was a remarkable innovation when Joseph Wharton, a selfeducated 19th-century industrialist, first proposed its establishment more than 135 years ago. Wharton School has continued innovating to meet mounting global demand for new ideas, deeper insights, and transformative leadership.

\section{Wharton Executive MBA Programme}

Length of Study: 2 years

Country of Study: Any country

Application Procedure: Applicants may apply online or contact Wharton for information. 


\section{For further information contact:}

The Wharton School Executive MBA Programme, University of PA, 224 Steinberg Conference Centre, 255 South 38th Street, Philadelphia, PA 19104-6359, United States of America.

Tel: $\quad$ (1) 2158985887

Fax: (1) 2158982598

Email: wemba-admissions@wharton.upenn.edu

\section{Whitehall Foundation, Inc.}

PO Box 3423, Palm Beach, FL 33480, United States of America.

\section{Tel: $\quad$ (1) 5616554474}

Email:_email@whitehall.org

Website: www.whitehall.org

Contact: Ms Catherine Thomas, Corporate Secretary

The Whitehall Foundation, Inc. through its programme of grants and grants-in-aid, assists scholarly research in the life sciences. It is the Foundation's policy to assist those dynamic areas of basic biological research that are not heavily supported by federal agencies or other foundations with specialized missions.

\section{Whitehall Foundation Grants-in-Aid}

Purpose: To better understand behavioural output or brain mechanisms of behaviour.

Eligibility: Open to researchers at the assistant professor level who have experienced difficulty in competing for research funds as they have not yet become firmly established. Senior scientists may also apply.

Level of Study: Research

Type: Research grant one year

Value: Up to US $\$ 30,000$

Length of Study: 1 year

Frequency: Annual

Country of Study: United States of America

Application Procedure: Applicants must contact the Foundation.

Funding: Private

Additional Information: For up to date policy, application information and important calendar deadlines please refer to the website www.whitehall.org/applying/

\section{Whitehall Foundation Research Grants}

Purpose: To better understand behavioural output or brain mechanisms of behaviour.

Eligibility: Open to established scientists of all ages working at accredited institutions in the United States of America. The principal investigator must hold no less than the position of assistant professor, or the equivalent, in order to make an application. The Foundation does not award funds to investigators who have substantial existing or potential support.

Level of Study: Research

Type: Research grant one year

Value: US\$30,000-US\$75,000 per year.

Length of Study: Up to 3 years

Frequency: Annual

Country of Study: Any country

Application Procedure: Please visit web-site @ www.white hall.org

Funding: Private

Additional Information: For up to date policy, application information and important calendar deadlines, please refer to the website www.whitehall.org/grants/

\section{Wilfrid Laurier University}

75 University Avenue West, Waterloo, ON N2L 3C5, Canada.

Tel:

(1) 5198841970

Email: webservices@wlu.ca.

Website: www.wlu.ca

Contact: Mr Al Hecht, International Relations

Laurier traces its roots to the opening of the Evangelical Lutheran Seminary in Waterloo more than 100 years ago in 1911. We have gone through several changes since then, and in 1973 our name changed from Waterloo Lutheran University to Wilfrid Laurier University. A Laurier education is about building the whole person: mind, body and spirit. We believe that your university career must lead to more than just a job to be considered a success; Laurier creates engaged and aware citizens in a culture that inspires lives of leadership and purpose.

\section{Viessmann/Marburg Travel Scholarship}

Purpose: To assist students wanting to study in Germany.

Level of Study: Postgraduate

Type: Scholarship 
Value: $€ 767$

Length of Study: 1 year

Frequency: Annual

Study Establishment: An approved place of study in Marburg.

Country of Study: Germany

Application Procedure: Contact University

Closing Date: 2 July

\section{Wilfrid Laurier University President}

Purpose: To reward significant contribution to the community as a volunteer or to the discipline as a scholar.

Eligibility: Full-time undergraduate students entering year 1. Minimum overall average of $95 \%$ in best six Grade $12 \mathrm{U}$ and/or Grade $12 \mathrm{M}$ courses or Ontario Academic Credits (OACs) (or equivalent).

Level of Study: Postgraduate

Type: Scholarship

Value: $\mathrm{C} \$ 23,000$ (C\$3,000 1st year; renewable based on academic performance for up to 4 years at $C \$ 5,000$ per year) 4th year of renewal eligibility for approved 5-year undergraduate programs only.

Length of Study: 1 year

Frequency: Annual

Study Establishment: Laurier University

Country of Study: Canada

Application Procedure: Apply online.

Funding: Trusts

Contributor: Dr Neale H. Taylor

For further information contact:

Email: fgps@wlu.ca

\section{Wingate Scholarships}

2nd Floor, 20-22 Stukeley Street, London WC2B 5LR, United Kingdom.

Tel: $\quad$ (1) 8007555550

Email:_enquiries@wingate.org.uk

Website: www.wingatescholarships.org.uk

Contact: Ms Sarah Mitchell, Administrator

Wingate Scholarships have been offered by the Foundation since 1988 but the Foundation itself was first established by my father as long ago as 1960 . Over the years when he was building up Chesterfield Properties, his commercial property and cinema-cum-theatre business, the Foundation became a major shareholder of this company. The first significant donation by the Foundation was in the late 1970s and was to the Royal London Hospital. It also funds an annual Book Prize in association with the Jewish Quarterly. There are currently six trustees, four from the family, who meet quarterly to decide on which organisations or projects, which have applied for grants, should receive them.

\section{Wingate Scholarships}

Purpose: To fund creative or original work of intellectual, scientific, artistic, social or environmental value and advanced music study.

Eligibility: Open to United Kingdom, Commonwealth, former Commonwealth, Israeli. Also open to European Union and Council of Europe country citizens provided that they are and have been resident in the United Kingdom for at least 3 years at start of award. Applicants must be over 24 years of age. No upper age limit is prescribed. No academic qualifications are necessary. Applications must be made in United Kingdom from a valid United Kingdom address.

Level of Study: Doctorate, Postdoctorate, Postgraduate, Research

Type: Scholarship

Value: Costs of a project, which may last for up to 3 years, to a maximum of United Kingdom $£ 10,000$ in any 1 year.

Length of Study: $1-3$ years

Frequency: Annual

Study Establishment: Any approved institute or independent research

Country of Study: Any country

Application Procedure: Applicants must be living in United Kingdom during the period of application. Applications from a valid United Kingdom address only are acceptable. Applicants must complete online application form from the website. Applicants must be able to satisfy the Scholarship Committee that they need financial support to undertake the work projected, and show why the proposed work (if it takes the form of academic research) is unlikely to attract Research Council, British Academy or any other major agency funding if they are United Kingdom applicants. All applications require two references to be submitted independently. Guidance is available on the website.

No. of awards offered: 228

Closing Date: 1 February

Funding: Foundation

Contributor: HHW Foundation

No. of awards given last year: 39

No. of applicants last year: 228 
Additional Information: The scholarships are not awarded for professional qualifications, taught courses or electives, or in the following subject areas: performing arts, fine art, business studies. Practising musicians (not composers) are eligible for advanced training, but apart from that, all applicants must have projects that are personal to them and involve either creative or original work. Only postgraduate students in their final two years can apply for scholarships to enable them to undertake field work, or in exceptional circumstances where an award has been withdrawn or closed, to complete a $\mathrm{PhD}$. Applications for studies or projects undertaken post doctorally are eligible, but not postdoctoral fellowship posts per se. Applicant must be based in United Kingdom when applying www.tau.ac.il/acad-sec/grantsite/abroad/britania\% 20wingate.htm

\section{For further information contact:}

Email: emma@shrimsley.com

\section{Winston Churchill Foundation of the United States of America}

600 Madison Avenue, Suite 1601, New York, NY 100221737, United States of America.

Tel: $\quad$ (1) 2127523200

Email: info@churchillscholarship.org

Website: www.churchillscholarship.org

Contact: Mr Michael Morse, Executive Director

Carl Gilbert, chairman of the Gillette Company, became the first Chairman of the Winston Churchill Foundation of the United States, which was established as a 501 (c) (3) US charity in 1959. In its early years, the Foundation made small travel grants to Churchill Overseas Fellows, distinguished senior faculty who would spend one year at the College. In the 1980s, funding was raised during gala dinners at which the Foundation granted the Churchill Award to an individual who has made outstanding contributions exemplifying Churchill's attributes and ideals. Today, the Scholarship is supported through a combination of the Foundation's investment reserves and through individual donations.

\section{Churchill Scholarship}

Purpose: The Churchill Scholarship provides funding to American students for a year of Master's study at the University of Cambridge, based at Churchill College. The program was set up at the request of Sir Winston Churchill in order to fulfill his vision of United States-United Kingdom scientific exchange with the goal of advancing science and technology on both sides of the Atlantic, helping to ensure our future prosperity and security.

Eligibility: An applicant for the Churchill Scholarship must be a citizen of the United States, either native born or naturalized, and must be a senior who is enrolled in one of the institutions participating in the Scholarship Program or a student who has graduated from one of those institutions within the past 12 months. Upon taking up the Churchill Scholarship, a Churchill Scholar must hold a bachelor's degree or an equivalent, and may not have attained a doctorate.

Type: Fellowship/Scholarship

Value: US $\$ 55,000$

Length of Study: 1 year

Frequency: Annual

Country of Study: United Kingdom

Application Procedure: Must be nominated by undergraduate institution.

No. of awards offered: 105

Closing Date: November

No. of awards given last year: 15

No. of applicants last year: 105

Additional Information: www.churchillscholarship.org/ apply.html

\section{For further information contact:}

600 Madison Avenue, Suite 1601, New York, NY 10022, United States of America.

\section{Winterthur}

Winterthur Museum, Garden and Library, 5105 Kennett Pike, Winterthur, DE 19735, United States of America.

Tel: (1) 8004483883

Email: tourinfo@winterthur.org

Website: www.winterthur.org

Contact: Thomas A. Guiler, Manager and Instructor, Academic Programmes

Winterthur is set amidst a 1,000-acre preserve of rolling meadows and woodlands. Designed by du Pont, its 60 -acre naturalistic garden is among America's best, with magnificent specimen plantings and massed displays of color. Graduate programs and a preeminent research library make Winterthur an important center for the study of American art and culture. 


\section{Winterthur Dissertation Research Fellowships}

Purpose: To encourage the use of Winterthur's collections for critical inquiry that will further the understanding of American history and visual and material culture.

Level of Study: Research

Type: Fellowship

Value: US\$7,000 per semesters

Length of Study: 1-2 semesters

Frequency: Annual

Country of Study: United States of America

Application Procedure: Applicants can download application form from the website.

Closing Date: 15 January

Funding: Foundation

Contributor: Winterthur

No. of awards given last year: 4

Additional Information: www.winterthur.org/education/ academic-programs/research-fellowships/fellowships-avai lable/

\section{For further information contact:}

Winterthur Museum Garden \& Library, 5105 Kennett Pike, Winterthur, DE 19735, United States of America.

Tel: $\quad$ (1) 8004483883

Email: tguiler@winterthur.org.

\section{Winterthur Postdoctoral Fellowships}

Purpose: To encourage the use of Winterthur's collections for critical inquiry that will further the understanding of American history and visual and material culture.

Eligibility: Open to scholars who hold the $\mathrm{PhD}$ degree, pursuing advanced research.

Level of Study: Postdoctorate, Research

Type: Fellowships

Value: Up to US $\$ 4,200$ per month.

Length of Study: 4 months

Frequency: Annual

Country of Study: United States of America

Application Procedure: Applicants can download the application form from the website.

Closing Date: 15 January

Funding: Foundation

Contributor: Winterthur

No. of awards given last year: 2

Additional Information: www.winterthur.org/education/ academic-programs/research-fellowships/fellowships-avai lable/

\section{For further information contact:}

Winterthur Museum Garden \& Library, 5105 Kennett Pike, Winterthur, DE 19735, United States of America.

Tel: $\quad$ (1) 8004483883

Email: tguiler@winterthur.org.

\section{Winterthur Research Fellowships}

Purpose: To encourage the use of Winterthur's collections for critical inquiry that will further the understanding of American history and visual and material culture.

Eligibility: Open to scholars pursuing advanced research.

Level of Study: Research

Type: Fellowship

Value: US $\$ 1,750$ per month

Length of Study: 1-3 months

Frequency: Annual

Country of Study: United States of America

Application Procedure: Applicants can download the application form from the website.

Closing Date: 15 January

Funding: Foundation

Contributor: Winterthur

No. of awards given last year: 21

For further information contact:

Email: researchapplication@winterthur.org

\section{Wolf Blass Wines International}

97 Sturt Highway, Nuriootpa, SA 5355, Australia.

Tel:

$$
\text { (61) } 885687311
$$

Email: visitorcentre@wolfblass.com.au

Website: www.wolfblass.com.au/brands/wolfblass/index. asp

Wolf Blass Wines International is public listed company and one of the Australia's top sellers of red and white wine. It is one of the best Australian wine-producing company.

\section{Wolf Blass Australian Winemaking Independent Study Scholarship}

Purpose: To support independent study related to winemaking in Australia. 
Eligibility: Open to culinary professional to conduct research and writing related to Australian winemaking and culinary traditions.

Type: Scholarship

Value: AU\$5,000

Country of Study: Australia

Application Procedure: All applicants are required to include a project proposal, an itemized budget detailing the use of this award and a tentative travel schedule with dates and locations. Check website for further details.

Additional Information: Applicant is additionally required to provide a current resume to qualify for this scholarship

\section{Wolfsonian-Florida International University}

1001 Washington Avenue, Miami Beach, FL 33139, United States of America.

\section{Tel: $\quad$ (1) 3055311001}

Email: info@thewolf.fiu.edu

Website: www.wolfsonian.org

Contact: Mr Jonathan Mogul, Fellowship Co-ordinator

The Wolfsonian-Florida International University or The Wolfsonian-FIU, located in the heart of the Art Deco District of Miami Beach, Florida, is a museum, library and research center that uses its collection to illustrate the persuasive power of art and design. For fifteen years, The Wolfsonian has been a division within Florida International University.

\section{Wolfsonian-FIU Fellowship}

Purpose: To conduct research on the Wolfsonian's collection of objects and library materials from the period 1885 to 1945 , including decorative arts, works on paper, books and ephemera. Eligibility: The programme is open to holder of Master's or doctoral degrees, $\mathrm{PhD}$ candidates, and to other who have a record of significant professional achievement in relevant fields.

Level of Study: Doctorate, Postdoctorate, Professional development

Type: Fellowship

Value: Fellowships include a stipend, accommodations, and round-trip travel.

Length of Study: 3-5 weeks

Frequency: Annual

Study Establishment: The Wolfsonian-Florida International University.

Country of Study: United States of America
Application Procedure: Applicants must complete an application form and submit this with three letters of recommendation. Contact the Fellowship Co-ordinator for details and application materials. Applicants may also download programme information and an application form from the website www.wolfsonian.fiu.edu/education/research

No. of awards offered: 26

Closing Date: 31 December

No. of awards given last year: 5

No. of applicants last year: 26

Additional Information: www.networks.h-net.org/node/ 73374/announcements/2914100/wolfsonian-fiu-fellowshipprogram

\section{For further information contact:}

Tel: (1) 3055352613

\section{Women's Studio Workshop (WSW)}

722 Binnewater Lane, PO Box 489, Rosendale, NY 12472, United States of America.

Tel: $\quad$ (1) 8456589133

Email: info@wsworkshop.org

Website: www.wsworkshop.org

Contact: Ms Ann Kalmbach, Executive Director

The Women's Studio Workshop (WSW) is an artist-run workshop with facilities for printmaking, papermaking, photography, book arts and ceramics. WSW supports the creation of new work through studio residency and annual book arts grant programmes and an ongoing subsidized fellowship programme.

\section{Artists Fellowships at WSW}

Purpose: To provide a time for artists to explore new ideas in a dynamic and co-operative community of women artists in a rural environment.

Eligibility: Open to women artists only.

Level of Study: Unrestricted

Type: Fellowship

Value: The award includes on-site housing and unlimited access to the studios. Cost to artists will be US\$200 per week, plus their own material.

Length of Study: Each fellowship is 3-6 weeks long. Fellowship opportunities are from September to June.

Frequency: Annual

Study Establishment: WSW 
Country of Study: United States of America

Application Procedure: Applicants must complete an application form, available on request or online at the website. One-sentence summary plus half-page description of proposed project, resume, 10 slides plus slide script, self addressed stampe envelope for return of materials.

No. of awards offered: 100

Closing Date: 15 October

Funding: Government, Private

Contributor: Private foundations

No. of awards given last year: 25

No. of applicants last year: 100

\section{Women's Studio Workshop Internships}

Purpose: To provide opportunities for young artists to continue development of their work in a supportive environment, while learning studio skills and responsibilities.

Eligibility: Open to emerging and established female artists

Level of Study: Unrestricted

Type: Internship

Value: A private room in our onsite housing and a stipend of US\$250/month.

Length of Study: $2-6$ months

Frequency: Annual

Study Establishment: WSW

Country of Study: United States of America

Application Procedure: Applicants must submit a curriculum vitae, 10 slides with slide list, 3 current letters of reference, a letter of interest that addresses the question of why an internship at WSW would be important and a stamped addressed envelope. Arts administration: 3 work samples, i.e. press releases, design samples, etc.

No. of awards offered: 150

Funding: Government, Private

Contributor: Private foundations

No. of awards given last year: 6

No. of applicants last year: 150

Additional Information: www.wsworkshop.org/residen cies/studio-internship/

\section{Woodrow Wilson National Fellowship Foundation}

104 Carnegie Center, Suite 301, Princeton, NJ 08540-631, United States of America.

Tel: $\quad$ (1) 6094527007

Email:_marrero@woodrow.org

Website: www.woodrow.org
The Woodrow Wilson National Fellowship Foundation identifies and develops the best minds for the nation's most important challenges. The fellowships are awarded to enrich human resources, work to improve public policy, and assist organizations and institutions in enhancing practice in the United States and abroad.

\section{The Millicent C. Mclntosh Fellowship}

Purpose: These fellowships are specifically intended for recently tenured faculty who would benefit from additional time and resources.

Level of Study: Postgraduate

Type: Fellowship

Value: A US $\$ 15,000$ stipend

Length of Study: 1 year

Frequency: Annual

Application Procedure: Contact the Foundation.

Closing Date: 31 March

Funding: Private

Contributor: Gladys Krieble Delmas Foundation.

\section{For further information contact:}

Tel: (1) 6094527007 ext. 301

Email: mcintoshfellowship@woodrow.org

\section{Woodrow Wilson MBA Fellowship in Education Leadership}

Purpose: To address the United States' twin educational achievement gaps-the one between the nation's lowest performing and its best schools, as well as the one between the nation's best schools and their top international competitors. The Fellowship seeks both to prepare leaders who can bring all American schools up to world-class levels of performance and to develop a new gold standard for preparing education leaders.

Eligibility: Fellows commit to serve for 3 years in approved school or district leadership positions within their states.

Level of Study: Postgraduate

Type: Fellowship

Value: Fellows will receive a stipend to cover tuition for the MBA program and other expenses.

Length of Study: The program will require 13-15 months of full-time study, depending on the institution-two summers and an academic year.

Frequency: Annual

Country of Study: Any country 
Application Procedure: Fellows must be nominated by a local education leader/colleague before they are eligible to apply. Contact information buntrock@woodrow.org

Closing Date: December

Additional Information: If you have already been nominated, see the respective pages for the WW MBA Fellowship at MSOE www.msoe.edu/community/academics/business/ page/2311/mba-in-education-leadership-overview, www. woodrow.org/mobile/fships/ww-ed-mba/

\section{For further information contact:}

Email: buntrock@woodrow.org

\section{Woodrow Wilson Teaching Fellowship}

Eligibility: The Woodrow Wilson Teaching Fellowship seeks to attract talented, committed individuals with science, technology, engineering, and mathematics (STEM) backgrounds - including current undergraduates, recent college graduates, midcareer professionals, and retirees - into teaching in highneed secondary schools. A qualified applicant should demonstrate a commitment to the program and its goals; have United States citizenship or permanent residency; have attained, or expect to attain by 30 June, a bachelor's degree from an accredited United States college or university; have majored in and/or have a strong professional background in an STEM field; have achieved a cumulative undergraduate grade point average (GPA) of 3.0 or better on a 4.0 scale (negotiable for applicants from institutions that do not employ a 4.0 GPA scale). Note: Prior teaching experience does not exclude a candidate from eligibility. All applications are considered in their entirety and selection is based on merit.

Level of Study: Graduate

Type: Fellowship

Value: US $\$ 30,000$-US $\$ 32,000$ stipend, with tuition arrangements varying by campus in Georgia, Indiana, and New Jersey. (Once Fellows are certified teachers at the end of the first year, they obtain salaried employment in high-need schools.)

Length of Study: 12-18 months plus 3-year teaching commitment

Frequency: Annual

Study Establishment: Fellowship is only available for use at specific schools in Indiana (Ball State University, Indiana University-Purdue University Indianapolis, Purdue University, and the University of Indianapolis); Michigan (Eastern Michigan University, Grand Valley State University, Michigan State University, University of Michigan, Wayne State University, Western Michigan University); and Ohio (John Carroll University, Ohio State University, University of Akron, and University of Cincinnati).
Application Procedure: Online application procedure and supporting documents. See www.wwteachingfellowship.org No. of awards offered: 1690

Funding: Foundation, Government, Private

Contributor: Ohio STEM, Lilly Endowment Inc., W K Kel$\operatorname{logg}$ Foundation, Choose Ohio First.

No. of awards given last year: 260

No. of applicants last year: 1690

Additional Information: University of Dayton and University of Toledo are also included in study establishment www. woodrow.org/fellowships/ww-teaching-fellowships/

\section{For further information contact:}

Tel: $\quad$ (1) 6094527007 ext. 141

Email: wwteachingfellowship@woodrow.org

\section{Woods Hole Oceanographic Institution (WHOI)}

266 Woods Hole Road, Woods Hole, MA 02543-1050, United States of America.

\section{Tel: $\quad$ (1) 5082892252}

Email:_information@whoi.edu

Website: www.whoi.edu/education

Contact: Janet Fields, Coordinator

The Woods Hole Oceanographic Institution is dedicated to advancing knowledge of the ocean and its connection with the Earth system through a sustained commitment to excellence in science, engineering, and education, and to the application of this knowledge to problems facing society. This is essential not only to advance knowledge about our planet, but also to ensure society's long-term welfare and to help guide human stewardship of the environment. WHOI researchers are also dedicated to training future generations of ocean science leaders, to providing unbiased information that informs public policy and decision-making.

\section{Postdoctoral Scholar Program}

Purpose: Eighteen-month Postdoctoral Scholar awards are offered to recipients of new or recent doctorates in the fields of chemistry, engineering, geology, geophysics, mathematics, meteorology, physics, and biology as well as oceanography. The awards are designed to further the education and training of the applicant with primary emphasis placed on the individual's research promise. 
Eligibility: In order to be eligible for one of these awards, applicants must have received their doctoral degree within the past 2-3 years.

Level of Study: Postdoctoral

Type: Fellowship

Value: US\$61,200 per year

Length of Study: 18 months

Frequency: Annual

Study Establishment: Woods Hole Oceanographic Institution

Country of Study: United States of America

Closing Date: 1 December

\section{Woods Hole Oceanographic Institution Postdoctoral Awards in Marine Policy and Ocean Management}

Eligibility: Open to Scholars and practitioners from relevant fields in the social sciences, natural sciences, law and management who are interested in applying their disciplinary training and experience to investigations which require a significant component of marine research. Applicants must have completed their doctorate degree or possess equivalent professional qualifications through career experience.

Level of Study: Postdoctorate

Value: Please contact the organization

Length of Study: 1 year

Frequency: Annual

Study Establishment: Woods Hole Oceanographic Institution Country of Study: United States of America

Additional Information: Award recipients in the programme have pursued such studies as the implications of oil exploration along the North eastern coast of the United States of America, problems of international law created by new developments in aquaculture and fish farming, economic benefits of some oceanographic research, a perceptual study of United Kingdom fishermen, and oceanic waste disposal www. woodrow.org/fellowships/ww-teaching-fellowships/

\section{Woods Hole Oceanographic Institution Postdoctoral Fellowships in Ocean Science and Engineering}

Purpose: To further the education and training of recent recipients of doctoral degrees in engineering science or with interests in marine science.

Eligibility: Open to United States citizens and foreign nationals who have earned a $\mathrm{PhD}$ degree in biology, physics, microbiology, molecular biology, chemistry, geology, geophysics, oceanography, meteorology, engineering or mathematics. Scientists with more than three years of postdoctoral experience are not eligible.

Level of Study: Postdoctorate

Type: Fellowship

Value: Please contact the organization

Length of Study: 1 year

Frequency: Annual

Study Establishment: Woods Hole Oceanographic Institution Country of Study: United States of America

Application Procedure: Applicants must complete and submit an application form with transcripts, reference letters, complete transcripts of undergraduate and graduate records, and a concise statement describing research interests. Further information and application forms may be obtained from the postdoctoral section of the website.

Funding: Government, Private

Additional Information: Award holders work in the laboratory under the general supervision of an appropriate member of the staff, but are expected to work independently on research problems of their own choice www.woodrow.org/ fellowships/ww-teaching-fellowships/

For further information contact:

Email: postdoc@whoi.edu

\section{Worcester College}

Walton Street, Oxford OX1 2HB, United Kingdom.

Tel: (44) 1865278300

Email: lodge@worc.ox.ac.uk

Website: www.worc.ox.ac.uk/

Worcester College was founded in 1714 , but there has been an institution of learning on the site since the late 13th century. Worcester College is a happy and supportive community, committed to combining academic excellence with becoming genuinely representative of our society.

\section{Drue Heinz Scholarship}

Purpose: Open to all graduate applicants for courses in the Humanities in which Worcester College admits students and who specify Worcester College as their first choice College. Eligibility: All applicants for courses in the Humanities in which Worcester College admits students and who specify Worcester College as their first choice college.

Level of Study: Graduate

Type: Scholarship 
Value: $£ 10,000$

Length of Study: 1 year

Frequency: Annual

Country of Study: United Kingdom

Application Procedure: 1. A completed application cover sheet (this can be downloaded from the college website at www.worc. ox.ac.uk/applying/graduates/graduate-scholarships). 2. An up-todate Curriculum Vitae. 3. A covering letter stating their reasons for applying for the particular course and providing information about applications they have made to relevant funding bodies.

No. of awards offered: 1

Closing Date: 5 March

Funding: Private

Additional Information: It is the applicant's responsibility to ensure that all application material is submitted by the deadline; incomplete applications will not be considered.

\section{World Bank Institute}

1818 H Street, NW, Washington, DC 20433, United States of America.

Tel: $\quad$ (1) 2024731000

Email:_pic@worldbank.org

Website: www.worldbank.org

Contact: Communications Officer

One of the largest sources of funding and knowledge for transition and development councils; The World Bank uses its financial resources, staff and extensive experience to help developing countries reduce poverty, increase economic growth and improve their quality of life.

\section{World Bank Grants Facility for Indigenous Peoples}

Purpose: To support sustainable and culturally appropriate development projector planed and implemented by and for Indigenous People.

Eligibility: Applicant must be an Indigenous People's community or not-for-profit/non-governmental Indigenous People's organization, must be legally registered in the country of grant implementation, the country must be eligible to borrow from the World Bank (IBRD and/or IDA). Applicant should have an established bank account in the name of the applicant organization and should demonstrate internal controls to govern the use of funds. Applicant should not have received a grant from the Grants Facility for Indigenous Peoples in the previous 2 years.

Level of Study: Professional development, Research
Type: Grant

Value: Proposed project budget requests should range between US\$10,000 and US\$30,000 and include a minimum contribution of $20 \%$ of the total project cost.

Frequency: Annual

Application Procedure: A complete application, not more than 10 pages, should be submitted.

Closing Date: 15 November

Contributor: The World Bank

Additional Information: www.siteresources.worldbank. org/INTINDPEOPLE/948158-1113428433802/20662536/ englishcall.pdf

\section{For further information contact:}

Fax: (1) 2025221669

Email: indigenouspeoples@worldbank.org

\section{World Bank Scholarships Program}

Purpose: The World Bank Scholarships Program contributes to the World Bank Group's mission of forging new dynamic approaches to capacity development and knowledge sharing in the developing world.

Eligibility: Details on Eligibility Criteria for each call for applications are provided in that call's Application Guidelines, and these detailed eligibility criteria are strictly adhered to. No exceptions are made.

Level of Study: Masters Degree, Postgraduate

Type: Scholarship

Frequency: Annual

Country of Study: Any country

Closing Date: 21 May

Funding: Private

Additional Information: If you are notified to be a semifinalist or if you are awarded a scholarship, you must inform and document to the JJ/WBGSP at that time if you have other sources of scholarship funds.

\section{World Federation of International Music Competitions}

104, rue de Carouge, CH-1205 Genéve, Switzerland.

Tel: $\quad$ (41) 223213620

Email: fmcim@fmcim.org

Website: wfimc-fmcim.org/

The World Federation of International Music Competitions contributes to the vibrancy of the music world by representing 
leading international music competitions and supporting them with valuable services and guidelines.

\section{International Beethoven Piano Competition Vienna}

Purpose: To encourage the artistic development of young pianists.

Level of Study: Unrestricted

Type: Competition

Value: $€ 50,000$

Frequency: Annual

Country of Study: Any country

Application Procedure: Apply online through the website www.beethoven-comp.at

Closing Date: 28 April

Funding: Private

\section{World Learning}

1015 15th Street, NW 7th Floor, Washington, DC 20005, United States of America.

Tel: $\quad$ (1) 2024085420

Email: info@worldlearning.org

Website: www.worldlearning.org

World Learning is a 501(c)(3) international nonprofit organization that focuses on international development, education, and exchange programs. The School for International Training (SIT) was established in 1964. SIT filled a need of returned Peace Corps volunteers by offering a graduate degree in International Development. The Vermont campus originally consisted of a small collection of dorms around a Carriage House on a scenic farm on the north end of Brattleboro. These early Peace Corps volunteers took lessons in foreign languages with materials and teachers from the language training from their service, and The School for International Training began to expand its offerings.

\section{School for International Training (SIT) Master of Arts in Teaching Program}

Purpose: To prepare language teachers committed to professional development and service in their field.

Eligibility: Open to persons of any nationality who are preparing for a language teaching career. Awards are available only to students studying at the School for International Training.

Level of Study: Graduate

Type: Scholarship

Value: Varies

Length of Study: A period that includes a time of student teaching and homestay. The programme is offered in a 1 year or 2 Summer format designed for working professionals.

Frequency: Annual

Study Establishment: SIT

Country of Study: Any country

Application Procedure: Applicants must complete an institutional financial aid application and should contact the Financial Aid Office for further details, by email at finaid@sit.edu

Additional Information: Students master technical teaching methodologies through language classroom practice, on campus coursework and a supervised teaching internship. Further information is available on the website www.sit.edu/mat

\section{For further information contact:}

Email: tesol@rennert.com

\section{Worshipful Company of Musicians}

1 Speed Highwalk, Barbican, London EC2Y 8DX, United Kingdom.

Tel: $\quad$ (44) 2074968980

Email: clerk@wcom.org.uk.

Website: www.wcom.org.uk

The Worshipful Company of Musicians is one of the Livery Companies of the City of London. Its history dates back to at least 1350. We are also known as The Worshipful Company of Musicians.

\section{Carnwath Scholarship}

Purpose: Open to any person permanently resident in the United Kingdom and 21-25 years of age. The scholarship is intended only for the advanced student who has successfully completed a solo performance course at a college of music. Eligibility: Open to any person permanently resident in the United Kingdom and 21-25 years of age. The scholarship is intended only for the advanced student who has successfully completed a solo performance course at a college of music.

Level of Study: Postgraduate 
Type: Scholarship

Value: $£ 4,150$ per year

Length of Study: Up to 2 years

Frequency: Annual

Country of Study: United Kingdom

Application Procedure: 1. Applicants must be nominated by principals of the Royal Academy of Music, the Guildhall School of Music, the Royal Northern College of Music, the Royal Scottish Academy of Music, Trinity College of Music, London College of Music, the Welsh College of Music, the Birmingham School of Music or the Royal College of Music. 2. No application should be made directly to the Worshipful Company of Musicians.

Closing Date: 30 April

Funding: Private

Additional Information: Website link error: www.sit.edu/mat

\section{For further information contact:}

Email: clerk@wcom.org.uk

\section{Writtle University College}

Lordship Road, Writtle, Chelmsford CM1 3RR, United Kingdom.

Tel:

(44) 1245424200

Website: writtle.ac.uk/

Writtle University College is one of the largest land-based university colleges in the United Kingdom; it is also one of the oldest. Set in the Essex countryside on a 220 hectare estate, Writtle, previously known as Writtle College, provides FE and HE programmes.

\section{Elinor Roper Scholarship 2020}

Purpose: This scholarship program is designed for marketing Writtle University College to provide students with the options of being able to study certain courses on a part-time basis.

Eligibility: To be considered for a Writtle University College Elinor Roper Scholarship award, students must be Home students and must apply by completing the ERS application form. This application must include a written statement of between $500-800$ words detailing the value the applicant expects to gain from study on the Master's programme and the way in which they anticipate using the experience after graduation to further their chosen career. If you have a "conditional offer" the scholarship will only be awarded if the conditions are met. Any applicant who defers entry will have to submit a new application for the academic year their studies will commence. Current Writtle University College students are not eligible to apply. The value of the scholarship will be deducted from the tuition fee invoice. It will be a condition of the scholarship that the successful applicant agrees to provide a student profile detailing their experience on the programme to be used in publications for the purpose of marketing Writtle University College and/or inclusion in the "University College Alumni Association" publication.

Level of Study: Masters Degree, Postgraduate, Postgraduate (MSc)

Type: Scholarship

Value: $£ 1,000$

Frequency: Annual

Country of Study: United Kingdom

No. of awards offered: Limited

Contributor: Writtle University

\section{Postgraduate International Scholarships}

Purpose: Scholarships are available for pursuing postgraduate programme.

Eligibility: The scholarship is only available to new postgraduate Writtle University College students. Applicants whose first language is not English are usually required to provide evidence of proficiency in English at the higher level required by the University.

Type: Scholarship

Value: For taught MA/MSc courses, the award will be worth $£ 1,000$; for MA conversion students the award will be delivered within the conversion year ONLY, as per the terms and conditions set out below.

Length of Study: 2 years

Frequency: Annual

Country of Study: Any country

Application Procedure: Applications to be sent via email. For more details, please refer website: www.scholarship-positions. com/writtle-university-college-postgraduate-internationalscholarships-uk/2017/10/23/

Closing Date: 31 August

Contributor: Writtle University

Additional Information: www.writtle.ac.uk/scholarships. cfm?Scholarship $=62 \&$ nohead $=1$ \&nofooter $=1$

\section{For further information contact:}

Email: student.recruitment@glasgow.ac.uk 